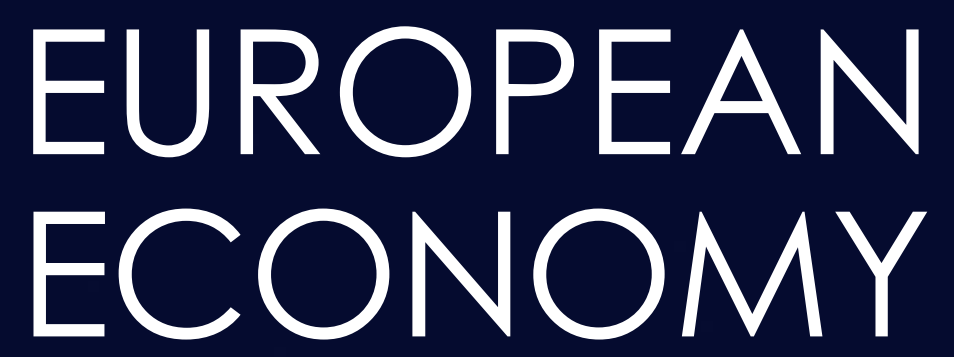

Economic Papers 319| April 2008

\title{
Recent developments in the European private equity markets
}

Kristiina Raade and Catarina Dantas Machado 
Economic Papers are written by the Staff of the Directorate-General for Economic and Financial Affairs, or by experts working in association with them. The Papers are intended to increase awareness of the technical work being done by staff and to seek comments and suggestions for further analysis. The views expressed are the author's alone and do not necessarily correspond to those of the European Commission. Comments and enquiries should be addressed to:

\section{European Commission}

Directorate-General for Economic and Financial Affairs

Publications

B-1049 Brussels

Belgium

E-mail: Ecfin-Info@ec.europa.eu

This paper exists in English only and can be downloaded from the website http://ec.europa.eu/economy finance/publications

A great deal of additional information is available on the Internet. It can be accessed through the Europa server (http://europa.eu)

ISBN 978-92-79-08244-3

doi: $10.2765 / 63664$

(C) European Communities, 2008 


\title{
RECENT DEVELOPMENTS IN THE EUROPEAN PRIVATE EQUITY MARKETS
}

\author{
Kristiina Raade and Catarina Dantas Machado ${ }^{1}$
}

\begin{abstract}
This paper examines market developments in venture capital and buyout investment in Europe and the United States through the analysis of funds raised, investments and exits. It discusses the profitability differential of European venture capital investment in comparison with the United States and suggests that it could originate in the different ways in which research is financed and the unequal supply of financing, notably from business angels, for young companies that are not sufficiently mature for venture capital financing. Investment performance measures used are the internal rate of return (IRR) and investment multiples. The analysis covers aggregated industry returns and venture capital funds' returns aggregated by vintage year. It relies on the VentureXpert ${ }^{\mathrm{TM}}$ private equity and venture capital performance database, maintained by Thomson Financial.
\end{abstract}

Keywords: venture capital, profitability, performance, IRR, Europe, United States

JEL classification: G10, G24

\footnotetext{
${ }^{1}$ European Commission, Directorate-General for Economic and Financial Affairs, Risk capital and SME financing Unit.

E-mail: kristiina.raade@ec.europa.eu; catarina.machado@ec.europa.eu
}

The views expressed in this paper are those of the authors only. No responsibility for them should be attributed to the European Commission. Sections of text may be quoted provided that full credit is given to the source. This paper was finalised in November 2007, therefore reflecting data available at that moment. Notwithstanding this, and, considering the available data on market developments, the validity of the main conclusions of and issues raised in the paper, in the view of the authors, is not essentially affected.

The authors would like to thank Thomson Financial for making data from the VentureXpert ${ }^{\mathrm{TM}}$ database available for analysis. 


\section{TABLE OF CONTENTS}

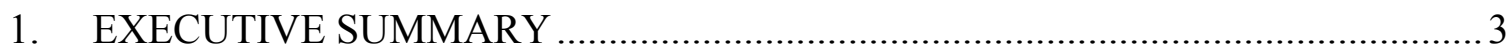

2. INTRODUCTION AND SCOPE OF THE PAPER .............................................. 4

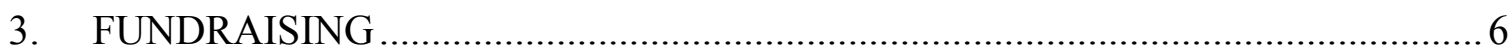

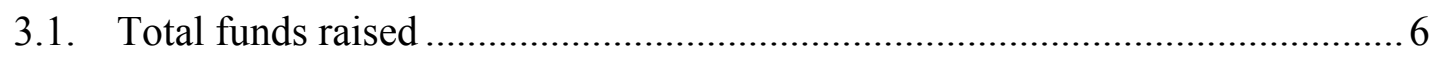

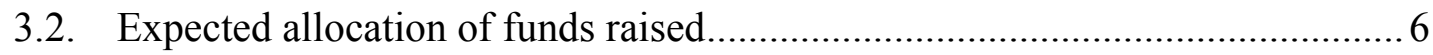

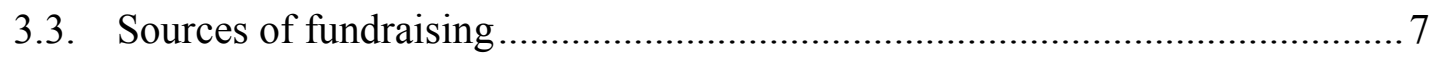

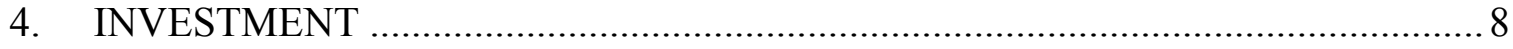

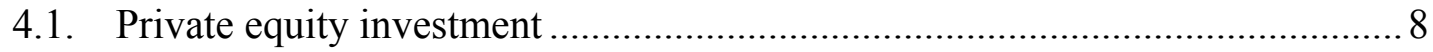

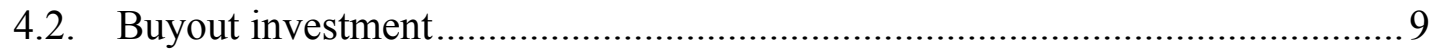

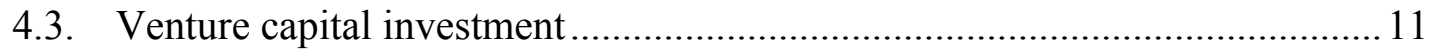

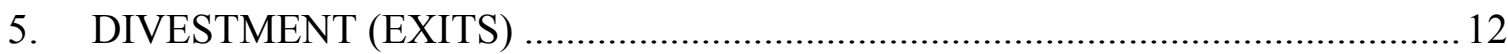

6. PRIVATE EQUITY INVESTMENT PERFORMANCE ...................................... 15

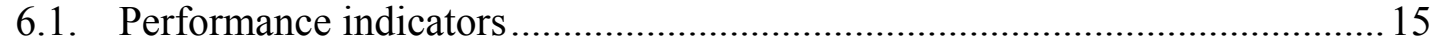

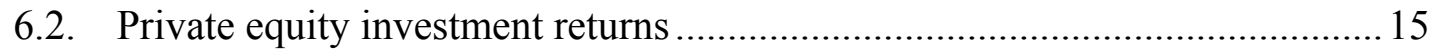

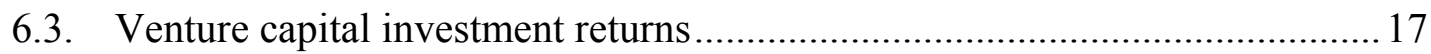

7. WHAT WILL THE FUTURE HOLD FOR EUROPEAN BUYOUT AND

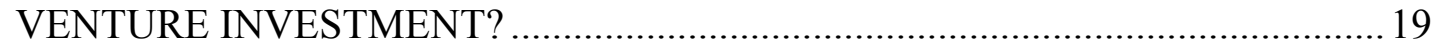

8. VENTURE CAPITAL INVESTMENT IN THE UNITED STATES......................20

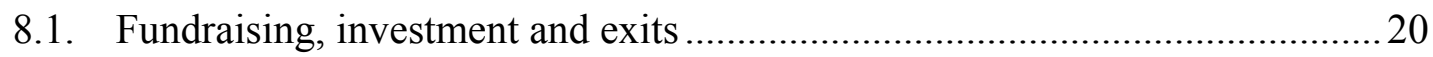

9. US PRIVATE EQUITY INVESTMENT PERFORMANCE .................................22

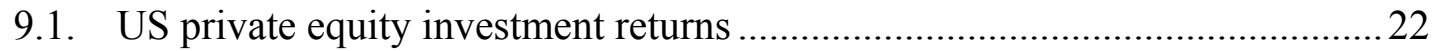

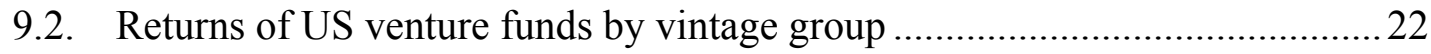

10. A CLOSER LOOK AT EARLY-STAGE VENTURE INVESTMENT ....................24

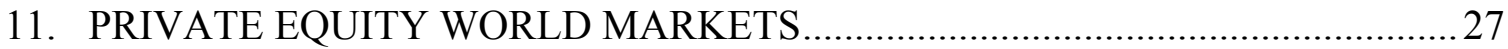

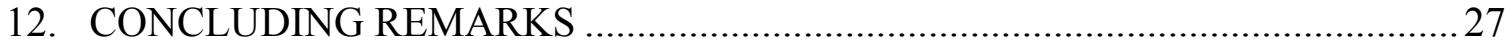

Annex I: Private equity investment performance measures

Annex II: Sources and quality of data 


\section{EXECUTIVE SUMmaRY}

This paper updates and expands previous analytical work by the Directorate-General Economic and Financial Affairs of the European Commission on private equity market activity and the performance of buyout and venture capital investment in Europe and the United States.

Charts $1 \mathrm{a}$ and $1 \mathrm{~b}$ below provide an overview of the evolution of the European private equity market between 1999 and 2006 through the main industry activity indicators: funds raised, investments and exits, as well as the total industry assets under management.

Chart 1a

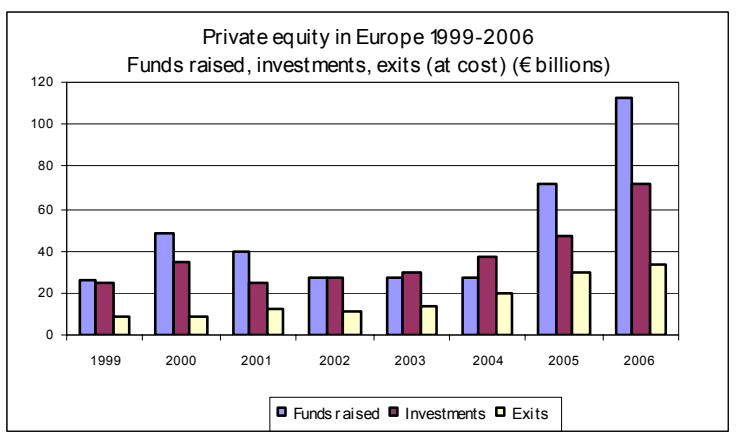

Data source: EVCA
Chart 1b

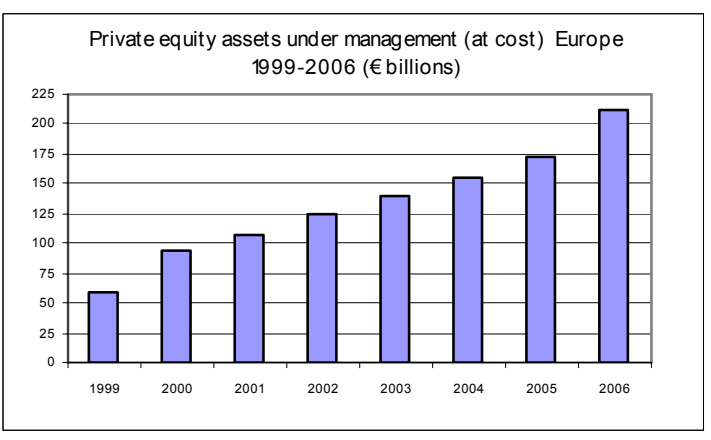

Data source: EVCA

According to the statistics of the European Private Equity and Venture Capital Association (EVCA), the amount of funds raised by private equity houses in Europe during 2006 reached a record $€ 112.3$ billion in 2006, up from $€ 71.8$ billion the year before. Around $75 \%$ of the total funds raised, or $€ 84.3$ billion, was earmarked for buyout investment. The share of venture capital in fundraising was $€ 17.5$ billion, or $15.5 \%$ of total funds raised, including $€ 5.9$ billion for early-stage venture capital investment. The successful fundraising was led by investor interest in buyout funds, but the relative share of venture capital in fundraising also increased, even if less dramatically. Low interest rates combined with the easy credit conditions that prevailed until recently helped create an ideal environment for leveraged buyout investment in 2006, and contributed to the consequent strong supply of funds for investment. The favourable fundraising environment was further reinforced by institutional investors' increasingly positive attitude towards the asset class underpinned by attractive returns generated by buyout investment. The appeal of venture capital also appeared to be slowly improving in response to an initial recovery in performance since the bursting of the technology bubble in 2000 .

Benefiting from favourable conditions, European private equity investment grew by $51 \%$ in 2006 , reaching a record $€ 71.2$ billion compared to $€ 47.1$ billion the year before. Predictably, buyouts accounted for the bulk of European private equity investment corresponding to $71 \%$ of total investment. But venture capital also contributed to the growth of private equity investment by increasing $40 \%$ to attain $€ 20.8$ billion. The increase in investment in 2006 was a natural reflection of good availability of funds for investment, which also fuelled an increase in private equity average deal sizes. The prices paid for companies taken over by private equity houses and venture capitalists were relatively high and increasing in 2006. Euro zone data points to an increase in average price/earnings (EBITDA) multiples from 6.9x in 2004 to 9.0x in 2006 for prices paid for acquisitions. 
Chart 2

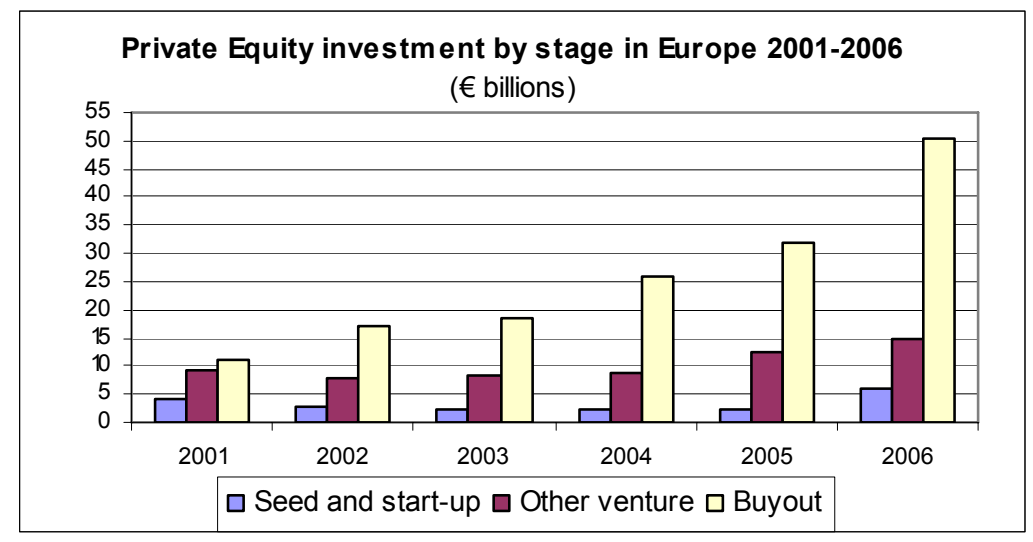

Data source: EVCA

In line with the favourable financial market conditions, European exit volumes also improved. In 1996, 4,448 companies were exited with total divestments measured at the cost of the relevant investments amounting to $€ 33.1$ billion, $11 \%$ above the 2005 figure, already a record. However, exit volumes recorded remained low compared to investments, which helps to explain the strong development of a secondary market in fund participations and investments.

The development of long investment horizon performance of European private equity investment was positive, although the overall picture remained mixed. European buyout investing was generating excellent returns for investors, while the returns in some segments of venture capital investment could be described as sustainable with some newer funds outperforming comparable funds in the US, but early-stage venture investment still showing on average negative returns.

The on-going correction in the credit markets combined with increased interest rates should be expected to put downward pressure on buyout investment. The lesser availability of loans to complement the own resources funding of buyout houses will make it more difficult to complete deals. The prevailing higher interest rates will make leverage less attractive and reduce potential buyout investment profit. Venture capital can be expected to be less affected due to its limited use of debt.

For a better understanding of the apparent weakness in European early stage venture investment, the structural differences in the pre-venture financing of innovation in Europe and the US need to be studied further. Notably the role of universities, foundations \& endowments and business angels in financing the pre-venture stages of the innovation value chain and preparing projects for venture investment should be studied.

\section{INTRODUCTION AND SCOPE OF THE PAPER}

The analysis presented below examines the current state of the European private equity market and the underlying trends. Aggregate European private equity investment has continued to grow rapidly over the past years, but the large and strongly performing buyout investment easily masks developments in the smaller venture capital segment. With a view to drawing conclusions specific to each of the two segments of the market, 
they have been treated separately to the extent possible. The analysis is somewhat constrained by the lack of disaggregated data for venture capital and buyout investment.

Again, with the purpose of identifying possible structural factors that could explain the apparent stronger role played by venture investment in the US in helping high-growth companies on their way, some comparative analysis on venture capital investment in Europe and United States is put forward. Also included is an update the analysis on the profitability of venture capital investment Europe and the United States published in March $2006^{2}$.

The analysis is largely based on information contained in the "annual Survey of PanEuropean Private Equity \& Venture Capital Activity", a yearly survey conducted by PricewaterhouseCoopers for the European Private Equity and Venture Capital Association (EVCA) and published in June.

The EVCA survey covers those European countries with meaningful private equity markets, notably 19 Member States $^{3}$, for the purposes of this note referred to as EU-19, plus Norway and Switzerland. Several sections in the analysis are based on EVCA's aggregated 'European' data, as opposed to EU or EU-19 data. This permits comparisons with annually updated data from earlier years only available in aggregated form. For the purposes of the analysis, 'Europe' and 'EU' can be taken as the same without risk of significant distortion.

For the US venture capital market data from the MoneyTree ${ }^{\mathrm{TM}}$ Survey by PricewaterhouseCoopers, Thomson Financial and the National Venture Capital Association (NVCA) has been used.

The analysis on the profitability of venture investment in Europe and the US relies on the VentureXpert ${ }^{\mathrm{TM}}$ database of Thomson Financial, who kindly allowed the relevant European Commission unit free access to the data.

Throughout the paper, the term 'private equity' has been used to denote all investment by the relevant investment funds, whether buyout or venture investment. This is consistent with EVCA definitions. It should be noted, however, that with the increased domination of buyout investment, in market parlance 'private equity' often refers to large scale buyout investment.

In the text that follows, EVCA terms are used to denote the different investment stages. The words 'early stage' refer to the aggregate 'seed', 'start-up' and 'other early stage' investment. The NVCA terminology of 'seed/start-up' followed by 'early stage' is only used in tables, where the intended meaning is clear.

2 "Profitability of venture capital investment in Europe and the United States", note to the EFC dated 29 September 2004, later published in the DG ECFIN Economic Papers series as Number 245.

3 Belgium, Czech Republic, Denmark, Germany, Greece, Spain, France, Ireland, Italy, Hungary, Netherlands, Austria, Poland, Portugal, Romania, Slovakia, Finland, Sweden and the United Kingdom 


\section{FUNDRAISING}

\subsection{Total funds raised}

The total funds raised by European venture capital and buyout houses in 2006 reached $€ 112.3$ billion, up by $56 \%$ from the $€ 71.8$ billion recorded the year before and by $309 \%$ compared to the $€ 27.5$ billion raised in 2004 . Given the unfavourable developments in financial markets during 2007, the 2006 fundraising may represent a peak similarly to the $€ 48.0$ billion raised in 2000 at the height of the technology bubble.

As in previous years, funds incorporated in the UK accounted for the largest share of total funds raised. In 2006, investors placed $€ 75.0$ billion for investment by UK funds, which corresponds to $67 \%$ of total funds committed. For a second consecutive year, UK funds accounted for approximately two thirds of total European fundraising. Relative to GDP, in addition to the UK, Swedish and Dutch funds were significant fundraisers with French funds at the European average.

With regard to the origin of funds placed with European fund managers, just $60.8 \%$ originated from European investors, down from $65.6 \%$ and $76.0 \%$ in 2005 and 2004, respectively. The share derived from US investors is growing and reached $28.8 \%$ in 2006. However, funds originating in other parts of the world showed even stronger growth. One explanation may be the increasing role of sovereign wealth funds.

\subsection{Expected allocation of funds raised}

The expected future use of funds raised for different classes of investment underlines the good health of the buyout market that continued through 2006 . The $€ 84.3$ billion raised for buyout investment corresponded to approximately $75 \%$ of total fundraising in line with previous years. Fundraising earmarked for venture investment reached $€ 17.5$ billion or approximately $15 \%$ of the total as in the year before. In the venture capital subsegments, the amount raised for early stage investment increased to $€ 5.9$ billion from $€ 4.4$ billion in 2005, but its relative share in expected allocations declined. For venture investment in technology, the picture is even less satisfactory with earmarking for early stage technology investment declining by $21 \%$ to $€ 2.9$ billion.

The generally low level of interest rates during past years has been a stimulus for investment in equities by institutional investors, including private equity. The very substantial growth in fundraising for buyout investment in 2006 obviously reflected investors' confidence in the continued good performance of the asset class. It remains to be seen whether or not the buoyant fundraising has continued during the second half of 2007. The sub-prime crisis has reduced the availability of credit and made banks more risk averse. The leveraged loans that habitually accompany buyout investment should be more difficult to raise making buyout transactions more difficult and slower to put together.

In the United States, according to NVCA data, the combined fund raising by private equity and venture capital funds reached $€ 104$ billion in 2006 and, slightly surprisingly, was below the corresponding European figure of $€ 112$ billion. A possible explanation is that the US buyout market leads the European one and has peaked a year earlier. Fundraising for buyout investment accounted for $78 \%$ of total private equity fundraising in $2006(73 \%$ in 2003$)$. 


\subsection{Sources of fundraising}

The available statistics on providers of funding for European private equity do not distinguish between venture capital and buyouts. It would seem obvious that investors would make a distinction between buyout investment and venture capital as asset classes and would make allocations in accordance with specific criteria to either type of asset. As the very much larger asset class, buyout investment dominates the EVCA figures on fundraising. In the absence of separate data, it is not possible to reliably analyse fundraising specifically for venture capital. The summary that follows is therefore only intended to give a general overview of the combined fundraising for buy-out and venture investment.

Chart 3

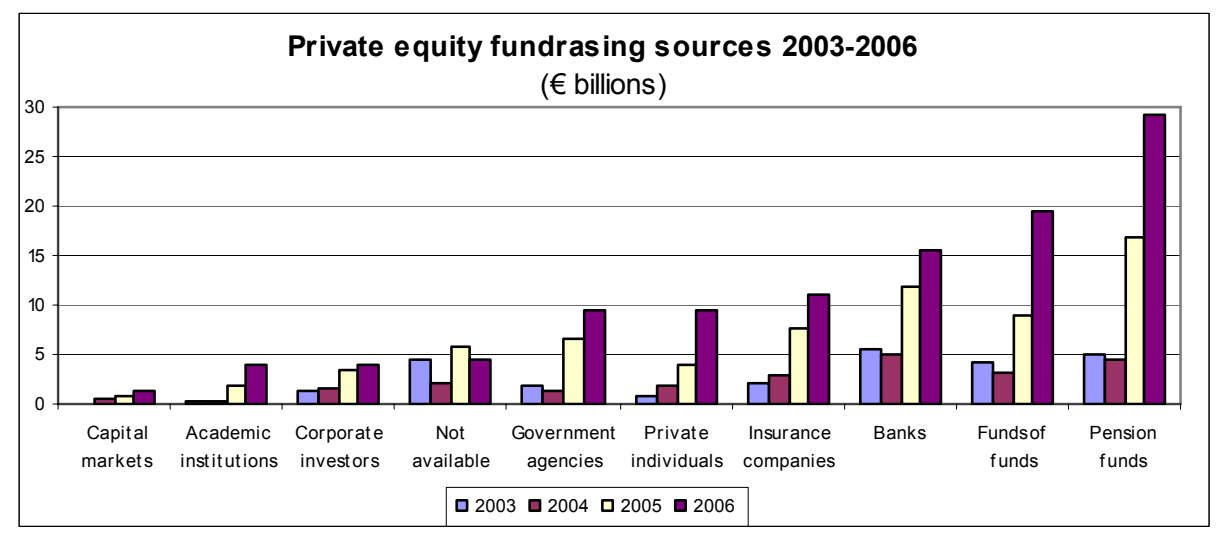

Data source: EVCA

Since 2003, the relative importance of the main investor classes in private equity has changed significantly with pension funds replacing banks as the largest source of funds. The by now very substantial amounts provided by pension funds for private equity investment could be seen as an indication that the European private equity market has reached a level of maturity that allows a significant group of pension funds to invest in the asset class in a sustained way, even if allocations could be assumed to remain below US levels. The perception of a lower risk environment driven by low debt default rates in companies that have been subject to a leveraged buyout has also reinforced the favourable market sentiment ${ }^{4}$.

In 2006, direct investment in private equity funds by pension funds reached $€ 29.3$ billion or $27.1 \%$ of total fundraising. UK incorporated funds received a proportionately high share of pension fund commitments to private equity. At $€ 24.4$ billion, the pension fund commitments received by UK incorporated private equity funds accounted for $83 \%$ of total European fund raising from pension funds. It would seem reasonable to assume that this reflects the interest of non-EU pension funds to participate in the European buyout market through London based pan-European funds. Proportionately, the share of funds provided by pension funds was also particularly high in Sweden in 2006 and possibly linked to the public AP Funds.

4 Special Comment "Rating Private Equity Transactions" by Moody's Investors Service, Global Credit Research, July 2007 
Despite the decreasing proportionate role of banks in the overall European fundraising for private equity during the past few years, they still are a major source of new funds in many Member States, including Austria, Belgium France, Italy, Netherlands, Portugal and Spain.

Funds of funds are an increasingly important conduit for investment in private equity. A placement in a fund of funds assures diversification to a number of ultimate investment funds and is often favoured by institutions without significant earlier experience of private equity investment or the resources to assess individual funds. In 2006, funds of funds were the second largest fundraising source and provided $€ 19.6$ billion, or $18.2 \%$ of total funds raised and were active in the vast majority of Member States. Fund of funds themselves raise their funds from all the same investor classes that fund private equity funds directly.

In 2006, the importance of private individuals as providers of funds for private equity investment increased sharply to $€ 9.6$ billion or $8.9 \%$ of total funds raised. The amount makes private individuals an investor class comparable in size to insurance companies and represents an astonishing development given that private individuals were the source of just $€ 0.8$ billion of private equity fundraising in 2003 . The attraction to private individuals should be the same as for institutions, namely the competitive returns produced by European buyout investment during the past few years.

The EVCA statistics record the amount of funds provided by government agencies as $€ 9.4$ billion in 2006, which corresponds to a nearly five-fold increase in the yearly funding that has customarily come from public sources. A step increase in the commitments of government agencies can first be observed in the 2005 statistics and could be linked to the emergence of sovereign wealth funds seeking to invest actively in the EU. During earlier years, the average $€ 2$ billion coming from governmental sources has been assumed to represent public schemes in support of early stage investment.

Private equity houses are increasingly looking to establish stock exchange quoted vehicles for raising permanent capital for investment. Such structures also help alleviate the general problem of the lack of liquidity of private equity participations in funds. It is likely that role of public markets as sources of capital for private equity investment will increase in the course of the coming years.

\section{INVESTMENT}

\subsection{Private equity investment}

As illustrated by Chart 1 presented in the Executive Summary, total European private equity investment, including both buyout and venture capital investment, grew sharply in 2006 to record levels. Total investment by private equity funds reached $€ 71.2$ billion, representing an increase of $51 \%$ over the $€ 47.1$ billion invested in 2005 . Predictably, at $€ 50.3$ billion or $71 \%$ of total, the best part was accounted for by buyout investment. However, venture capital investment also grew strongly attaining $€ 20.8$ billion, an increase of $40 \%$ over the $€ 15.0$ billion venture investment in 2005 . 
European private equity investment levels continue to vary strongly between Member States as shown by Chart 4 , in which investment by country of management refers to the investment made by funds managed from the Member States concerned in both domestic companies and companies domiciled abroad. Investment by country of destination refers to private equity investment received in a country from both home funds and funds located abroad.

\section{Chart 4}

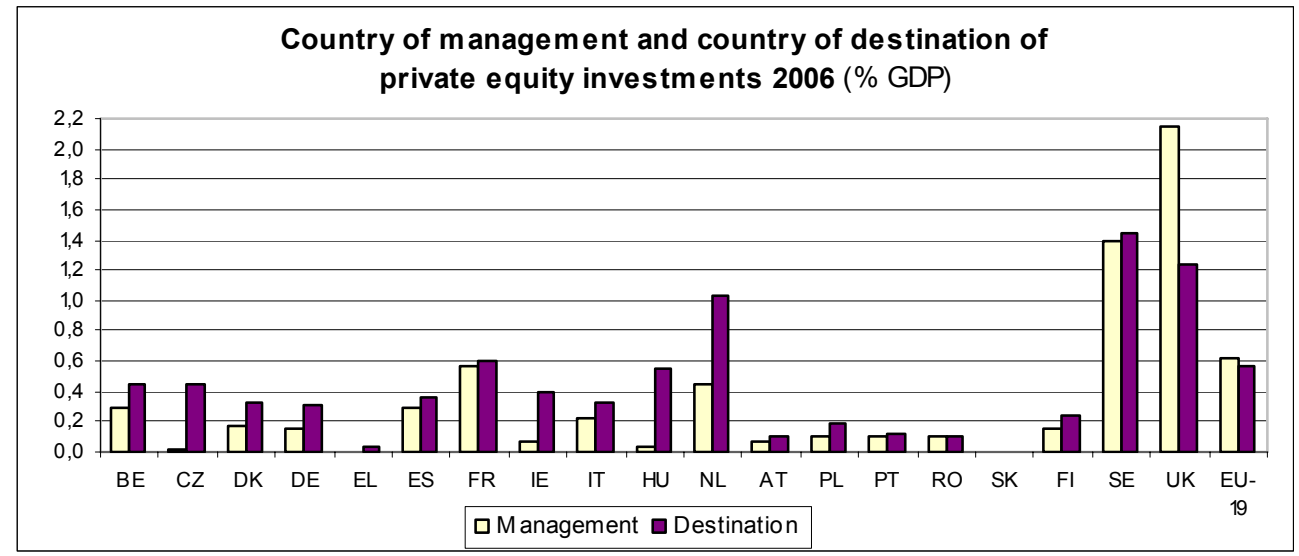

Data source: EVCA

In EU-19, the average private equity investment by country of management expressed in percentage of GDP was $0.61 \%$ in 2006 . The average conceals significant differences between Member States. In the United Kingdom the ratio was 2.15\%, in Sweden 1.39\%, followed by France with $0.56 \%$ and the Netherlands with $0.45 \%$.

According to EVCA data, United Kingdom-based private equity funds invested $€ 40.1$ billion in 2006 with France as the next largest market with $€ 10.1$ and Sweden with $€ 4.3$ billion.

Investments by UK based funds accounted for 59\% of total EU-19 private equity investment. In 2001 the equivalent figure was 28\%, suggesting an increase in the relative weight of the UK private equity industry in Europe and a trend towards a concentration of resources. In 2006 the UK was the only Member State where the level of funds managed exceeded domestic investments, whereas as recently as in 2000-2001 a large number of Member States managed more funds than was invested domestically.

\subsection{Buyout investment}

The increase in the amount of buyout investment was mainly driven by an increase in the number and the average size of the so-called mega-buyouts, i.e. take-over of companies valued at or above $€ 1,000$ million, but in terms of number of transactions they accounted for just 31 out of a total of 1653 companies bought out in 2006 but were up from 12 in 2005.

In 2006 private equity funds invested $€ 19.5$ billion of their own funds in mega-buyouts. As all these transactions are leveraged and can involve debt to the tune of 4-5 times the fund investment, the actual amounts invested by the funds and the banks that back them could be put at around the $€ 100$ billion figure. Along with this pattern comes the trend towards market concentration whereby important capital commitments are managed by 
few hands. Symptomatically, in 2006 just 13 funds accounted for $47 \%$ of total funds raised 5 .

There appears to be market consensus that the relative price that buyout houses are willing to pay for large companies has substantially increased during the past years. For obvious reasons, data on private equity deal prices is difficult to obtain, even by proprietary databases. However, some data is available on mid-market buyout EBITDA multiples ${ }^{6}$ for Euro zone countries. The recently established mid-market index Argos Epsilon, which tracks M\&A and buyout transactions in the Euro zone, indicates that the average acquisition multiples increased from $6.9 \mathrm{x}$ in 2004 to $9.0 \mathrm{x}$ in $2006^{7}$. Although the data does not cover the whole EU private equity market place, significantly the UK is not included, it provides a flavour of current market conditions and allows an objective view of the situation of Euro zone mid-market buyout investment, which accounts for $65 \%$ of total mid market in Europe ${ }^{8}$.

The willingness of private equity houses to pay increasingly high prices for acquisitions over the past years could be explained by the combined effect of increasing competition among asset managers and the high liquidity of financial markets during the period. Successful fundraising by private equity funds is putting pressure on them to invest, in turn giving rise to competition of attractive opportunities between funds. Adding to this, many hedge funds also take an interest in buyout investing. The added financing required to pay for the resultant higher prices has been readily available from the loan markets. At the same time, lending conditions have been easy allowing increased leverage of transactions. It could also be said that the ability to leverage up transactions has allowed private equity houses to maintain the profitability of their investments in spite of higher price/earnings multiples. It should be expected that there will be a market correction in due course.

In 2006, the number of small buyouts, i.e. buyouts of companies valued at less than $€ 50$ million, was 1.289 , up by $12 \%$ from the 1.151 recorded in 2005 , involving private equity investments of $€ 4.8$ billion or, on average, $€ 3.7$ million per company. As many of these transactions can be assumed to involve management buyouts concluded with the objective of unlocking growth, the steady increase in the numbers of target companies should be seen as a positive development. Moreover, the average size of private equity commitment suggests that in this segment of the buyout market it is possible to create substantial economic value with relatively small amounts of cash.

5 EVCA/Thomson/PricewaterhouseCoopers press release 12 June 2007.

6 Price paid expressed as a multiple of the target company's EBITDA, or earnings before interest, taxes, depreciation and amortisation.

7 Indice Argos Epsilon Mid Market, press conference of March 2007, www.argos-soditic.com. It covers all EU-15 Euro zone countries except Greece.

8 Fitchratings research conclusions on EV/EBITDA multiples of recycled LBOs rated by the agency in 2004-2005 point to the same direction. "European Recapitalised LBOs: All Systems Go" by Jay Djemal, Pablo Mazzini, Michelle de Angelis and Edward Eyerman, European Leveraged Finance Special Report, January 2007. 


\subsection{Venture capital investment}

European venture investment grew strongly in 2006 and, for the first time, the $€ 20.8$ billion recorded by EVCA matched the $\$ 26.3$ ( $€ 21)$ billion of venture investments in the US. Measured against GDP, the importance of venture investment in Europe has grown steadily and reached $0.18 \%$ of GDP in 2006 , as compared to $0.20 \%$ in the US, and up from $0.10 \%$ three years earlier in 2003 .

Similarly to the US, European venture investment is not evenly distributed across the region, but the level of investment varies strongly between the Member States as shown by Chart 5 below which shows the development of venture capital investment in relation to GDP in 2003-2006. The particularly high figures shown for the UK could be explained, firstly, by the presence in London of a number of venture capital houses that are capable of investing on a cross-border basis and, secondly, by government actions to encourage early-stage venture investment. Generally, it would seem justified to remark that in many Member States governmental schemes have had a positive effect on the level of early stage venture investment.

Chart 5

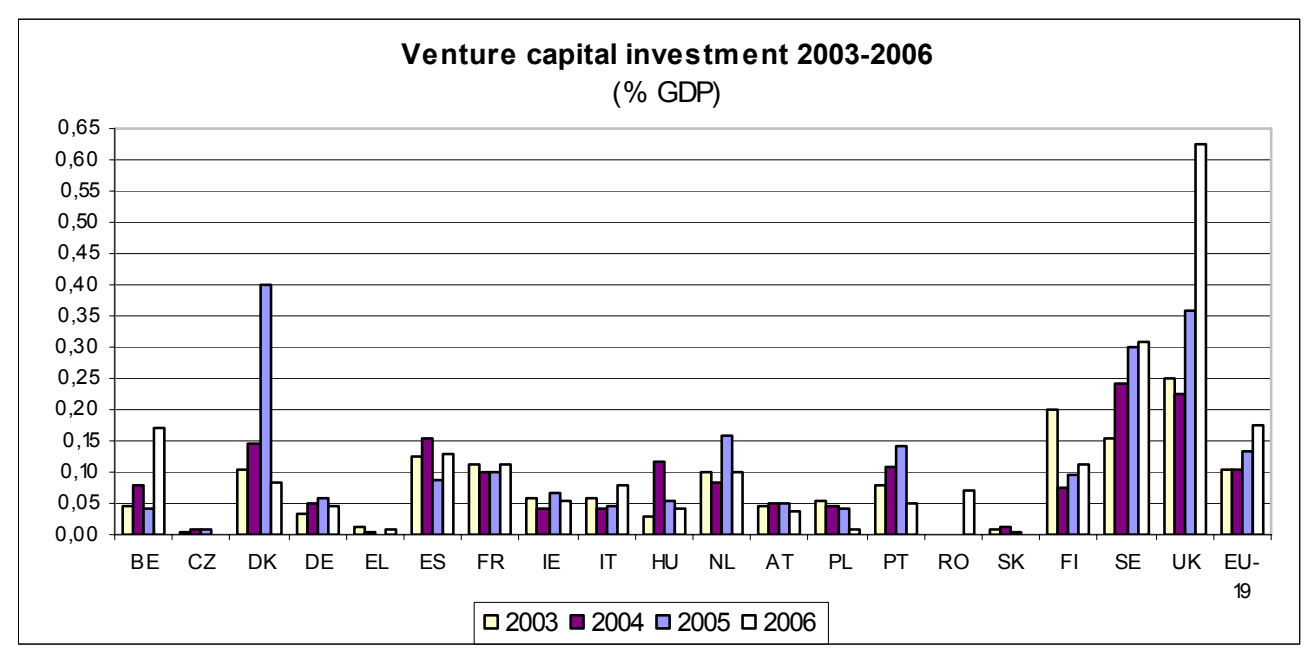

Data source: EVCA

Early stage investment, essentially investment in companies without a track record but with the potential for high growth, represents the segment of private equity investment involving appreciably higher risks than other segments as well as potentially higher profits. Early stage investment is a vital element in the innovation value chain that enables the transfer of technology from laboratory to industry. Also in this segment the level of investment is higher in the UK than in other Member States as shown by Chart 6 and could be partly explained by the existence of an organised business angel community that feeds opportunities to venture capitalists. 


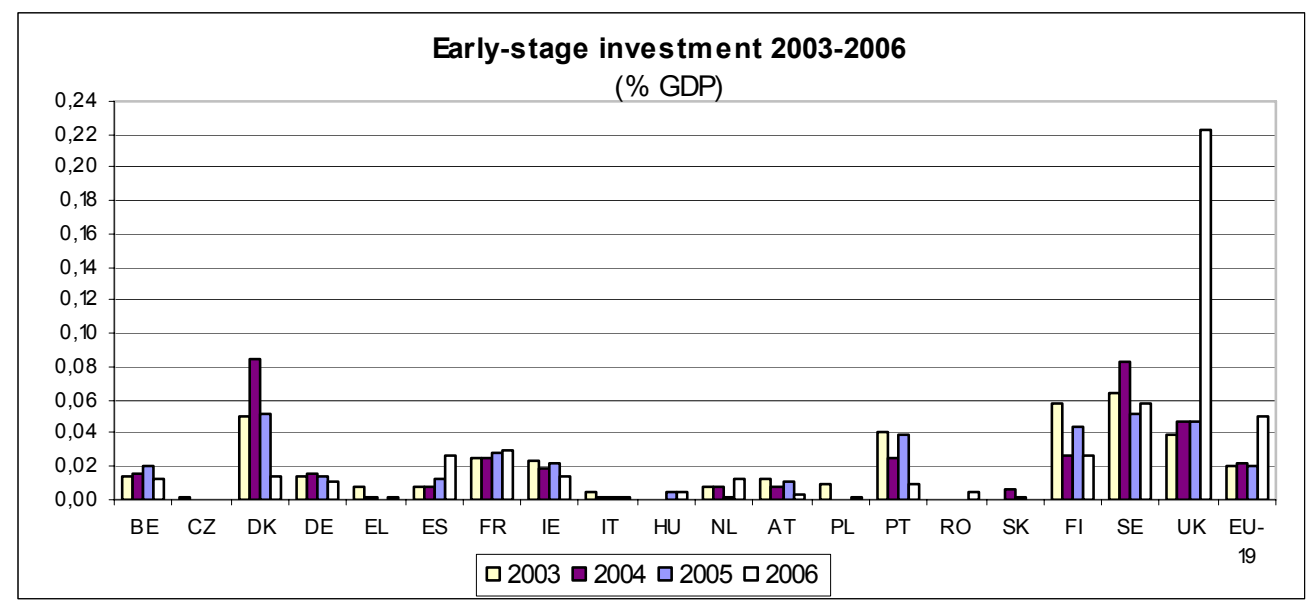

Data source: EVCA

Data on venture capital investment in technology by European venture capital funds is not available, but according to EVCA figures, the combined buyout and venture capital investment in high-tech companies increased substantially in 2006 . It went up $63 \%$ to $€ 13.1$ billion from $€ 8.1$ billion in 2005 . Fundraising allocations for early stage high-tech investment were down in 2006, however.

\section{DiVESTMENT (EXITS)}

Divestment, or exit, is the last transaction in the private equity investment transaction sequence. The sale of a private equity investment allows the investor to realise the value created by the investee company during the investment period. In the case of venture capital investment, the value would usually have been created through the growth of the company, whereas in the case of buyouts, rationalisation of operations, asset sales and financial engineering are often involved. As a result of a successful exit, as an investor, the private equity investor is replaced by a new investor whose risk/return criteria match the development stage and prospects of the company.

According to EVCA statistics, in 2006 total European private equity divestments, recorded at the original cost of the relevant investments, amounted to $€ 33.1$ billion, having reached $€ 29.8$ billion in 2005 and $€ 19.6$ billion in 2004 . The growth in exit volumes appears steady, but volumes look low in relation to fundraising even after taking into account that exits naturally lag investment by several years (Chart 1a).

The actual cash realised from the divested investments should obviously have been higher than the at cost divestment figures, but actual exit price data is not available from public sources. Last year, investments in 4.448 companies were divested either in whole or in part, down from 4.830 in 2005 and 5.914 in 2004.

Charts $7 \mathrm{a}$ and $7 \mathrm{~b}$ below illustrate the relative importance of different types of exits by breaking down total exits figures by divestment volumes and numbers of companies divested. The market figures available for analysis do not distinguish between venture and buy-out investment for divestment data. In order to form a picture of the possible differences in the divestment patterns in these two categories, the analysis that follows seeks to identify differences by comparing, on one hand, divestments in terms of the cost of the underlying investments, which figures are dominated by buyout divestments, and 
on the other, in terms of number of companies, which figures in turn should be more influenced by venture related divestments.

Chart 7a

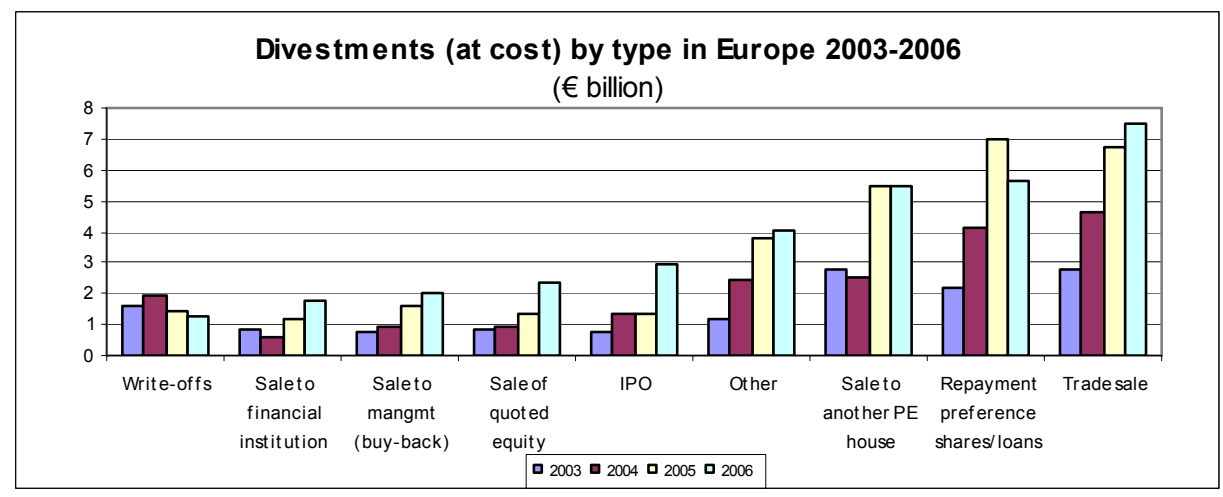

Data source: EVCA

Chart 7b

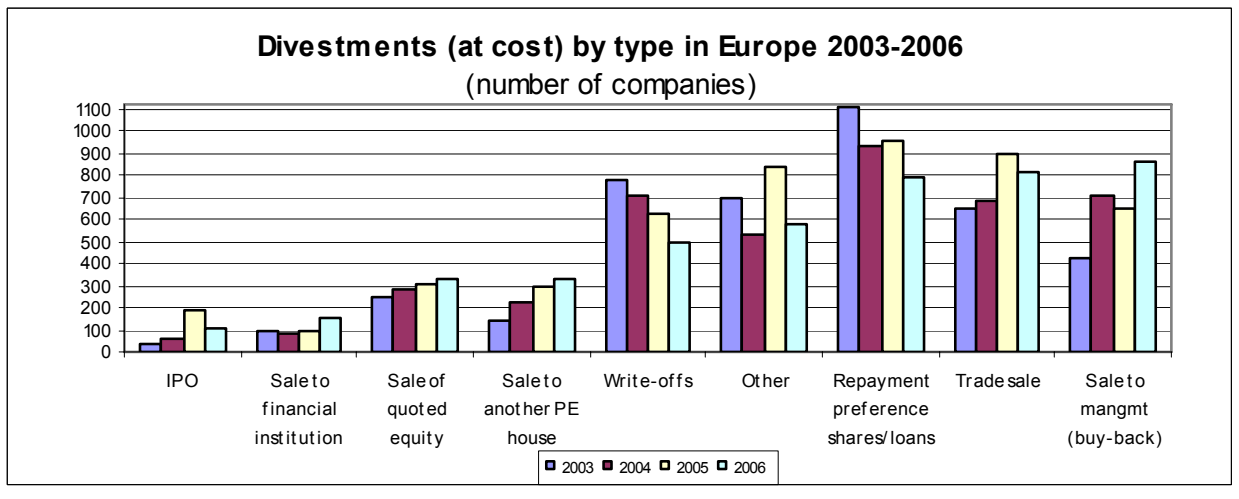

Data source: EVCA

Trade sale, denoting a sale to a strategic buyer, typically to a company in the same sector as the divested company, remains the most important exit route. The average at cost value of investments divested through trade sale was $€ 9.3$ million in 2006 and $€ 7.5$ in 2005 , which is consistent with venture and small buyout investment. The number of companies exited this way was 809 , down from 900 the year before.

Receipts of repayments of quasi-equity and other loans extended to investee companies by private equity houses themselves, at $€ 5.7$ billion $^{9}$, was the second largest among the divestment types recorded by EVCA. Divestments of this nature obviously do not involve receipt of payment from an unrelated buyer the way a trade sale would, but the cash transmitted to the private equity investors comes from the resources of the investee companies.

Exits through the sale to another private equity house or venture fund accounted for $€ 5.5$ billion in 2006. Secondary sales remained the third largest exit route by volume. Secondary investors play an important role as liquidity enhancers in a market that is fundamentally illiquid. From the perspective of the exited company, the exit to a

9 Because of the nature of the instruments, the actual funds returned to the investors from quasi-equity and other loans corresponds to the cost of the original investment assuming that the database does not take interest payments into account. 
'secondaries'- fund is not considered an ultimate exit in the sense that the new investors are temporary in the same way as the original investors. For a company to be held by two, three or even four consecutive private equity investors is not uncommon in today's LBO market 10. For the recycled investee companies, this may mean frequent management changes and operational adjustment.

In 2006, there were 108 divestments through Initial Public Offering (IPO), down from 184 the year before. The aggregate at cost value of the investments exited by IPO more than doubled, however, to $€ 3.0$ billion from $€ 1.3$ billion in 2005 increasing the average at cost value of the original investments to $€ 27$ million from $€ 7.2$ million in 2005 . The figures appear small, but it should be remembered that an IPO seldom involves more than a relatively small part of company's shares. The increase could thus be explained by a higher share of larger buyout investments exited this way.

Exits via write-off, i.e. the cancellation of an investment from the fund's portfolio with no associated positive cash-flow were at a particularly low level in 2006. According to EVCA figures, the value of total write-offs was $€ 1.3$ billion, the lowest level since 2000. The favourable developments in write-offs is partly off-set by the growth of exits through 'other' means which category includes changes in ownership events usually associated with less successful investments, including sale back to management.

When examining the European private equity exit patterns it should be borne in mind that what constitutes an exit may be defined in different ways depending on the vantage point of the observer. EVCA data includes as an exit event any event involving change of ownership, plus the repayment of debt owed to private equity firms, whereas the US exits data published by NVCA data only takes account of trade sales and IPOs on the grounds that they are the only types of exit that represent a genuine liquidity event. Neither association records dividend recapitalisations.

From the point of view of institutional investors a dividend recapitalisation may also be regarded an exit event as it results in cash being returned to the investor. Dividend recapitalisation is a transaction in which the existing shareholders of a company, in this case private equity firms, alter its financial structure by paying out a dividend that is financed by debt. Such transactions are frequently done as means of returning cash to private equity investors early and can be an alternative to an IPO, a trade sale or a secondary sale.

Aided by the benign conditions in credit markets, the volume of dividend recapitalisations has grown phenomenally during the last 2-3 years. In 2006, dividend recapitalisations by private equity firms reached US $\$ 38.2$ billion ${ }^{11}$ across the globe, up by $51 \%$ from the year before. Putting a ball-park figure on dividend recapitalisations in Europe requires an educated guess: Europe accounts for approximately $40 \%{ }^{12}$ of global private equity investment, which means that its proportionate share in dividend

10 FitchRatings - Corporate Finance, Leveraged Finance/European Special Report "Recapitalised LBO transactions: The only way out?" by Jay Djemal, Pablo Mazzini, Michelle de Angelis and Edward Eyerman, 18 January 2006

11 According to figures by Dealogic, Reuters article 27.9.2007

12 PricewaterhouseCoopers, Global Private Equity Report 2006 
recapitalisations would have been $€ 12$ billion in 2006 . It could be argued that the figure is overstated as growth in dividend recapitalisations was particularly high last year and use of the instrument in the US market, which leads the European market, could have grown faster. On the balancing side, the European buyout market is not behind the US in sophistication and likely to make early use of the most advanced financial technology. Either way, the total volume of dividend recapitalisations in Europe is likely to have been a substantial figure in 2006. With the drying up of credit supply, the use of dividend recapitalisations should have peaked for the time being.

Alongside such exit events as the repayment of quasi-equity and other loans, dividend recapitalisations are an additional type of exit that is financed from the resources of the investee company. In 2006, the cash flows out of European investee companies linked to various types of loans and dividend recapitalisations could be assumed to have been very significant in relation to, for instance, the level of investments.

Finally, as a general observation, the aggregate cost value of exits involving a genuine liquidity event, e.g. divestment through IPO, sale of quoted equity or trade sale, at $€ 12.9$ billion or $39 \%$ of total exits, appears low.

\section{PRIVATE EQUITY INVESTMENT PERFORMANCE}

\subsection{Performance indicators}

The most commonly used methods for determining the profitability of venture capital and private equity investment are the internal rate of return (IRR) and investment multiples, such as the 'Distributions to Paid In Capital' ratio (DPI), which already figure in earlier work by the authors on the profitability of private equity investment. For ease of reference an introduction to the performance measures is included in Annex I.

\subsection{Private equity investment returns}

Table 1 below illustrates the performance of private equity investment in Europe by showing the IRRs of the different segments for 1-, 3-, 5-, 10- and 20-year time horizons to 30.9.2006. The most illustrative is the 10-year time horizon (the return made by an investor with a proportionate share in all funds in the database during the period 19972006) as it corresponds to the typical life of a private equity fund and thereby investors' typical holding periods. 
Table 1

European venture capital and private equity investment

Pooled average IRR\% for investment horizon of 1, 3, 5, 10 and 20 years as of 30.9.2006

\begin{tabular}{|l|c|c|c|c|c|}
\hline Stage/Horizon & $\begin{array}{c}\mathbf{1} \text { Year } \\
\mathbf{2 0 0 6}\end{array}$ & $\begin{array}{c}\mathbf{3} \text { Years } \\
\mathbf{2 0 0 4 - 2 0 0 6}\end{array}$ & $\begin{array}{c}\mathbf{5} \text { Years } \\
\mathbf{2 0 0 2 - 2 0 0 6}\end{array}$ & $\begin{array}{c}\mathbf{1 0} \text { Years } \\
\mathbf{1 9 9 7 - 2 0 0 6}\end{array}$ & $\begin{array}{c}\mathbf{2 0} \text { Years } \\
\mathbf{1 9 8 7 - 2 0 0 6}\end{array}$ \\
\hline Early stage & -10.2 & -0.7 & -6.4 & -0.9 & 0.0 \\
\hline Development & 0.0 & 5.9 & 0.2 & 9.2 & 8.8 \\
\hline Balanced & 0.0 & 14.4 & 3.7 & 12.8 & 10.3 \\
\hline All venture & $\mathbf{- 6 . 6}$ & $\mathbf{6 . 8}$ & $-\mathbf{0 . 8}$ & $\mathbf{6 . 8}$ & $\mathbf{6 . 9}$ \\
\hline Buyouts & 36.1 & 13.2 & 7.1 & 14.3 & 13.9 \\
\hline Generalist & 0.0 & 4.3 & -0.5 & 8.1 & 8.3 \\
\hline All Private equity & $\mathbf{3 3 . 3}$ & $\mathbf{1 0 . 4}$ & $\mathbf{3 . 9}$ & $\mathbf{1 1 . 2}$ & $\mathbf{1 0 . 6}$ \\
\hline
\end{tabular}

Data source: EVCA/Thomson Financial (Data extracted in March 2007)

The figures show that on average European venture investment produces acceptable, if not overly attractive returns in later stage investing, but the average returns of early stage investing are persistently negative. It should be noted, however, that investment performance varies strongly between funds. Some funds may be very profitable, whereas others may produce losses keeping the average IRR figures down.

European buyout investment, on the other hand, has produced good returns. The very high average returns observed for the one year time horizon could be expected at least partly to reflect cash receipts created through dividend recapitalisations, which can be assumed to have reached a particularly high level in 2006.

In an effort to identify possible trends in the profitability of the different private equity segments, Chart 8 below presents 10-year time horizon average IRRs to the end of 2003, 2004, 2005 and 2006. Overall, the picture that emerges suggests stability. The average returns of venture investment appear to be increasing as the bursting of the technology bubble becomes distant. There is some way to go, however, before average venture returns reach double digits.

\section{Chart 8}

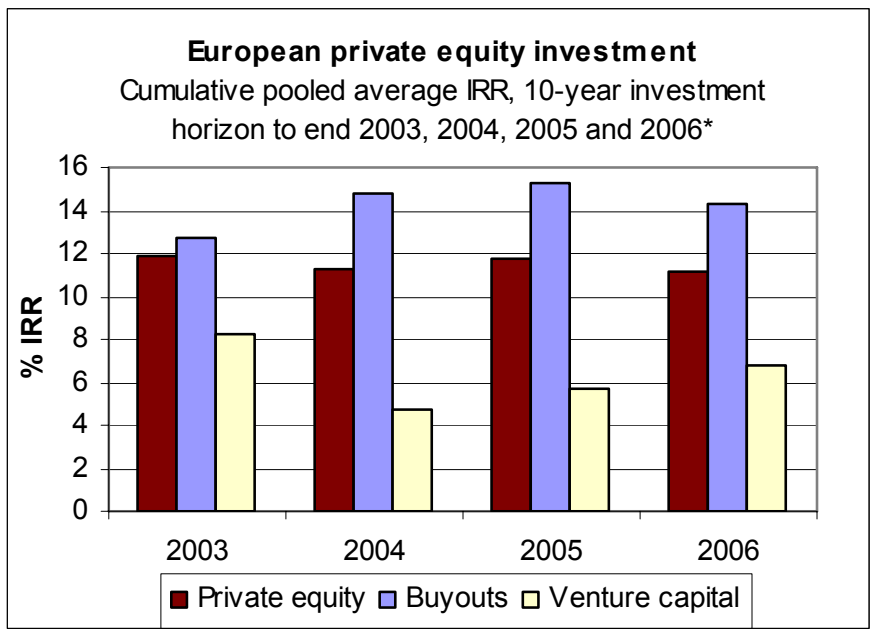

Data source: Thomson Financial; *2006 data as of 30.9.2006 


\subsection{Venture capital investment returns}

The profitability of European venture investment is analysed further by examining the average pooled IRRs of funds by grouping them by the year of establishment, the 'vintage year'. This way the life cycle of the funds can be better taken into account.

Chart 9 below shows the cumulative pooled average IRRs of venture funds formed in the years 1983-2005, no new funds having been included in the database in 2006, as at the end of 2003 and 30.9.2006.

Chart 9

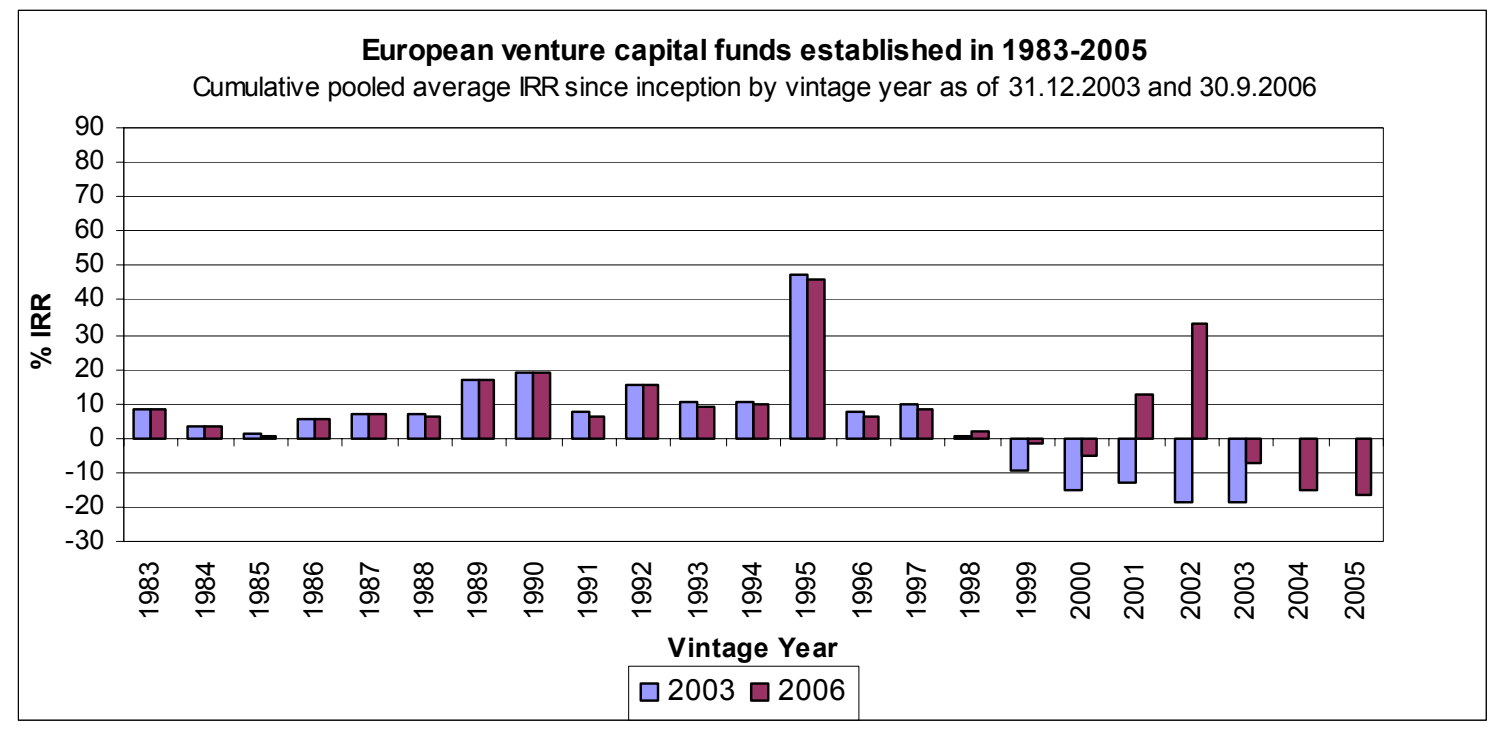

Data source: Thomson Financial

For ease of comparison between Europe and US the same art scale is used as in Chart 13

As could be expected, the older funds established up to 1992 do not show a noticeable change in profitability. The funds should have mostly been fully divested already at the end of 2003 and their results therefore unchanged at later reference points.

All vintages from 1993 to 1997 show a reduction in returns from end 2003 to end 2006. Lower than expected sale prices may have been achieved for investments exited during the period or the value of investments held marked down. (In this context it should be noted that the valuations of assets held by active funds are based on management estimates.)

From 1998 onwards, the vintages can be assumed to be composed of active funds in different stages of their life-cycle. The J-curve of venture fund profitability is clearly visible as well as the move of the bottom of the curve to the right on the scale between the two observation points of 31.12.2003 and 30.9.2006.

A certain trend towards increased average IRRs can be observed in the post-2001 vintages. The 2001 vintage IRR goes up from $-12.9 \%$ in 2003 to $12.3 \%$ in 2006 and in the 2002 vintage the IRR goes up from $-18.3 \%$ to $33 \%$ suggesting that investments are being exited successfully halfway in the funds' average life of 10-12 years. Given that the level of cash distributions in these vintages also increased during the same period, as discussed below, it is possible that European venture investment is now well into recovery after the difficulties caused by the bursting of the technology bubble. 
Chart 10 also shows the cumulative average pooled returns of venture capital funds belonging to the 1983-2005 vintages to end 2003 and to 30.9.2006, but measured by distributions to paid in capital (DPI), i.e. the amounts of cash in relation to capital invested that an investor with a proportionate share in every fund in every vintage would have received back.

\section{Chart 10}

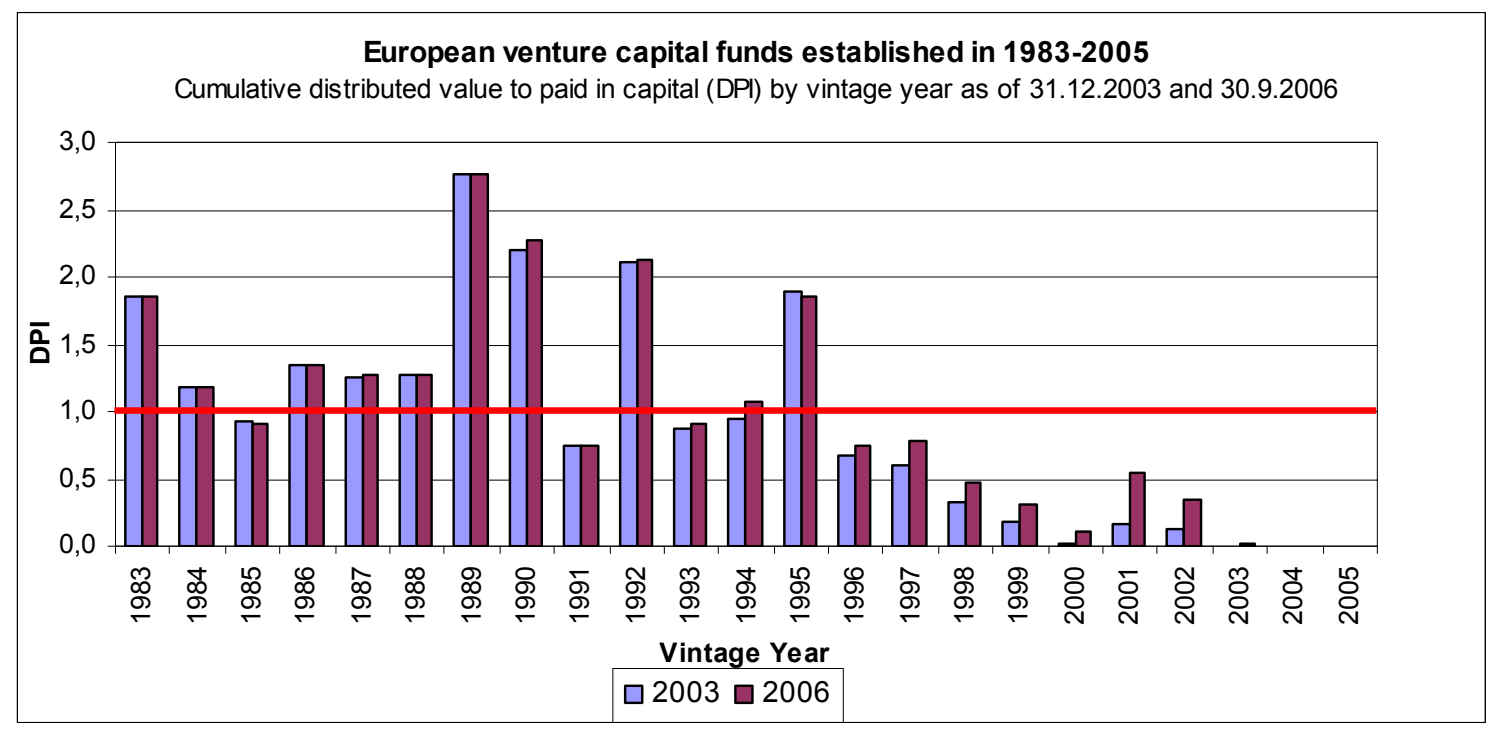

Data source: Thomson Financial

For ease of comparison between Europe and the US, the same scale has been used in Charts 11 and 16.

At the reference point of the end of September 2006, there were still a few funds in the 1990-1994 vintages, aged between 17 and 13 years, registering slight increases in cumulative DPI. Given that the number of funds in the sample corresponding to these vintages is the same in 2003 and 2006 (except one fund less in 1990 vintage group) the data denotes actual distribution of small amounts of cash to their investors by funds which despite their age are still active. This pattern of distributions also suggests a late divestment or liquidation process.

Groups of funds established between 1998 and 2000 have relatively low distributions for their age if compared with the 2001 and 2002 vintages. Although these funds still have some years of life ahead, say 4-6 or perhaps even longer, the current level of distributions - DPIs of 0.48, 0.31 and 0.11 respectively for 1998, 1999 and 2000 - does not suggest a very generous final return. During the period in which these funds were established, the time of the technology bubble, acquisition prices were particularly high.

Funds established in 2001 and 2002, immediately after the technology bubble burst, with a DPIs of 0.54 and 0.35 respectively look more promising in comparison to those belonging to the 1996-2000 vintage series. This could be explained by a more selective investment policy and lower asset prices in the wake of the market correction in 2000. The particularly high distributions shown by the 2001 vintage could be largely due to the sale of Skype to Ebay for \$2,500 million (€2.1 billion), an amount high enough to impact IRR and DPI statistics given that the annual venture European venture investment amounts to some $€ 14$ billion.

Venture capital funds belonging to the 2003, 2004 and 2005 show zero DPIs. They are still at the stage of screening investment opportunities and initial portfolio building, and are not yet making cash distributions to their investors. 


\section{WHAT WILL THE FUTURE HOLD FOR EUROPEAN BUYOUT AND VENTURE INVESTMENT?}

As this is being written in October 2007, the conditions for private equity investment are changing in a way that is outside the control of the industry. Increased interest rates eat to the profits of investee companies, notably those that may have been saddled by high levels of debt in connection with a buyout, or as a result of a dividend recapitalisation having been used as a divestment method. The industry view is that provided that the fundamentals of the markets in which investee companies operate are not dramatically changed, the rising cost of debt should not lead to a substantial correction in the private equity market or an extensive increase in levels of defaults by investee companies. The real effects of the rising costs may only become visible in two or three years time, however.

The bubble-conditions that developed in the buyout market during the past few years, the sustainability of which the industry itself had already been questioning for some time, now seem to have come to an end as a result of the on-going correction in the credit markets. The completion of leveraged buyouts has become noticeably more difficult in line with the tighter supply of debt, not only because of the lesser capacity of banks to accommodate debt in their balance sheets, but also the reduced appetite of the far and widely dispersed buyers that until recently were happy to purchase packaged LBO-debt. Globally, there have been 76 abandoned large-scale buyout deals worth $\$ 202$ billion so far this year compared to 55 failed bids amounting to $\$ 99$ billion in the same period last year ${ }^{13}$. It could be assumed that concerning the smaller end of buyouts, the drying up of debt may not be as dramatic. The immediate consequence should be more costly debt and a negative impact on deal profitability.

Turning to the exit patterns that can be observed in the European private equity industry, the total volume of divestments looks low in comparison to investments, although a systematic assessment of holding periods is not possible with the available data. At the same time, the share of divestments that were the result of a genuine liquidity event, i.e. the sale of assets to an unrelated buyer outside the private equity industry, at $39 \%$ of total volume looks low. The ability of the private equity industry to operate year after year at such low levels of real turnover in assets is surprising to an external observer. Technically, the exit methods that are based on cash paid by investee companies to the owner funds and the growth of the in secondary funds provide an explanation. However, there remains a question on the extent to which the increase in fundraising is needed to fund the extended periods of time that investee companies may remain in the ownership of successive funds. The long term sustainability of the slow return of assets to owners outside the private equity industry could be questioned.

The setback that the unfavourable developments in the credit market have delivered to buyout investment can be expected to be met by many creative solutions by the industry. The funds could pursue new businesses, including taking minority stakes in publicly 
quoted companies in the event that the amount of funds raised exceed what can be invested in buyouts.

Turning to venture capital, the latest available data in both investment activity and performance give rise to optimism that this segment of the private equity market may have turned the corner. In another positive sign, during the past few years, the cumulative investment amounts have exceeded the amounts that were shown as earmarked for venture capital in fundraising. Venture capital investment will be less affected by the correction in the credit market. The extent to which there may be positive spill-over from the buyout side in terms of the transfer of financial and management resources to venture investing remains to be seen. In the integrated private equity houses that are active in both segments of the market such a development would certainly be possible, but the number of such management companies is limited.

\section{VENTURE CAPITAL INVESTMENT IN THE UNITED STATES}

Similarly to Europe, the relevant industry association has a central role in setting the parameters for data collection in the US. As the focus of the two associations, EVCA and NVCA, is not identical there are differences in the coverage of the published data. In Europe data is collected for both buyout and venture capital investment whereas, in line with the activities of NVCA, US data is limited to venture capital investment. The US market analysis presented below is therefore necessarily limited to venture capital.

\subsection{Fund raising, investment and exits}

The United States venture capital market functioned well in 2006. As illustrated by Chart 11, the fundraising, investment and exit data suggest that market activity has settled at a sustainable level after the build-up and subsequent bursting of the technology bubble.

Chart 11

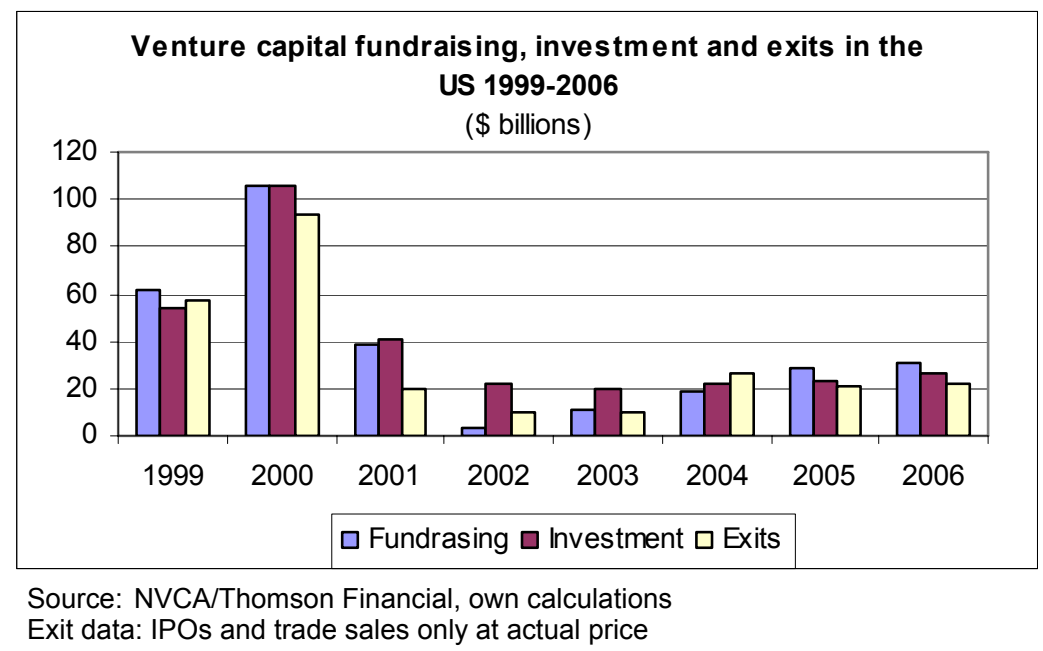

Fundraising, which suffered greatly in the aftermath of the technology bubble, appears to have returned to even keel. Whilst there is little publicly available data on the breakdown of funding sources for the US market, according the Institutional Limited Partners Association (ILPA), the major investors in US venture capital are institutional investors, 
notably public and private pension funds, but also foundations, endowment funds, corporations and wealthy individuals. ILPA brings together 170 member organizations, mostly from North-America, who on average allocate $17 \%$ of their total assets to the asset class. The comparable European allocations should be just a fraction of the US allocations.

While appearing to be working well, the US venture industry now appears much less superior in relation to Europe than at the turn of the century as shown by Charts $12 \mathrm{a}$ and $12 \mathrm{~b}$, which compare fundraising and investment in the two regions. The real difference between Europe and the US is of course in early stage venture investment, where the US is much ahead of Europe.

Chart 12a

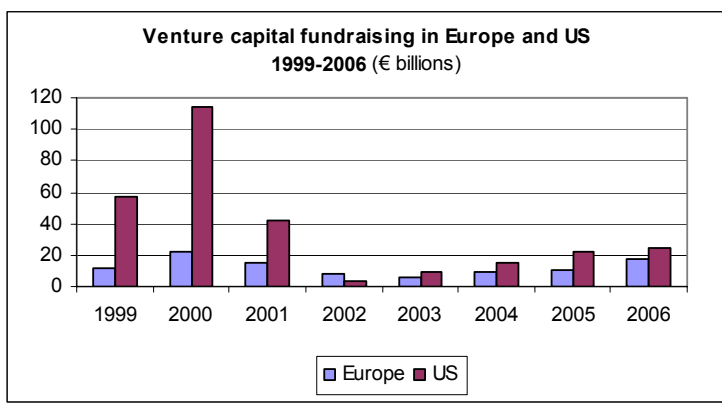

Data source: NVCA/EVCA/Ameco
Chart 12b

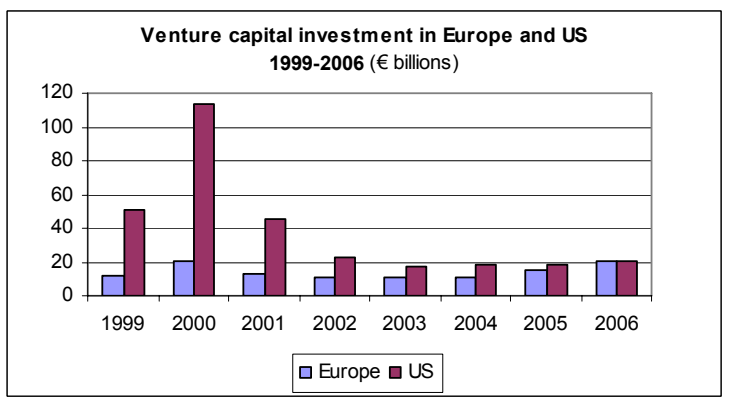

Data source: NVCA/EVCA/Ameco

Total investment by US venture funds amounted to $\$ 26.3$ billion in 2006 up from $\$ 23.1$ billion in 2005 and $\$ 22.5$ billion in 2004 . There seems to be a growing participation of US-based investors and venture capitalists in overseas venture capital markets, including, inter alia, Europe, China and India. According to recently compiled NVCA data, in 2006, the first year for which data is available, US venture capitalists invested \$2 billion in China and India alone. According to an industry-sponsored report, an increasingly significant number of US-based venture capitalists stated their plans to invest outside the United States ${ }^{14}$.

Exits from venture capital investments made by venture capitalists in the US market were stable in 2006 and in line with previous years' fundraising. Similarly to 2005, in 2006 exits via IPO accounted for $22 \%$ of total divestment volume, while the sale of investments to a strategic buyer, trade sale, was the route for $78 \%$ of total divested venture capital. It should be noted that the US exit statistics do not record other types of divestments, including write-offs that are included in the European market statistics.

A meaningful comparative analysis of venture capital exit activity in Europe and the US is not possible in the absence of relevant data. The European figures published by EVCA only give aggregated private equity exit figures without break-down to buyout and venture exits. As previously discussed, there are also significant methological differences in the compilation of EVCA and NVCA exit statistics. 


\section{US PRIVATE EQUITY INVESTMENT PERFORMANCE}

\subsection{US private equity investment returns}

The overall, average private equity IRRs for 10-year investment horizon to 30.9.2006, at $11.2 \%$, was exactly the same in Europe and the US. Under the headline figure, there are significant differences, however, as illustrated by Table 2. European buyouts, with their robust $14.3 \%$ IRR by far exceeded the equivalent investment return in the US, where the IRR was only $8.8 \%$. It was the strength of the US venture investment, notably early stage investment that makes the overall private equity return identical to that in Europe.

Table 2

US venture capital and private equity investment

Pooled average IRR\% for investment horizon of 1, 3, 5, 10 and 20 years as of 30.9 .2006

\begin{tabular}{|l|c|c|c|c|c|}
\hline Stage/Horizon & $\begin{array}{c}\mathbf{1} \text { Year } \\
\mathbf{2 0 0 6}\end{array}$ & $\begin{array}{c}\mathbf{3} \text { Years } \\
\mathbf{2 0 0 4 - 2 0 0 6}\end{array}$ & $\begin{array}{c}\mathbf{5} \text { Years } \\
\mathbf{2 0 0 2 - 2 0 0 6}\end{array}$ & $\begin{array}{c}\mathbf{1 0} \text { Years } \\
\mathbf{1 9 9 7 - 2 0 0 6}\end{array}$ & $\begin{array}{c}\mathbf{2 0} \text { Years } \\
\mathbf{1 9 8 7 - 2 0 0 6}\end{array}$ \\
\hline Early/Seed & 2.6 & 5.5 & -5.4 & 38.3 & 20.5 \\
\hline Development & 7.5 & 12.9 & 1.9 & 16.9 & 14.6 \\
\hline Later stage & 14.5 & 8.9 & 1.8 & 9.0 & 13.7 \\
\hline Total venture & $\mathbf{7 . 0}$ & $\mathbf{9 . 1}$ & $\mathbf{- 1 . 2}$ & $\mathbf{2 0 . 5}$ & $\mathbf{1 6 . 5}$ \\
\hline Buyouts & 21.6 & 15.6 & 2.2 & 8.8 & 13.2 \\
\hline Mezzanine & -0.4 & 4.8 & 5.6 & 5.9 & 8.4 \\
\hline All Private equity & $\mathbf{1 6 . 5}$ & $\mathbf{1 3 . 1}$ & $\mathbf{6 . 8}$ & $\mathbf{1 1 . 2}$ & $\mathbf{1 4 . 0}$ \\
\hline
\end{tabular}

Data source: Thomson Financial

Long investment horizon returns of venture capital investment in the US remain high. They still significantly outperform European venture capital investment with 10 -year IRR of US venture investment at $20.5 \%$ as compared to $6.8 \%$ in Europe. The profitability levels of seed and start up investment measured by the 10-year IRR remain significantly higher in the US. While in the US investment in early/seed funds posted a 10-year IRR of $38.3 \%$, the equivalent European figure remained at $-0.9 \%$. Given the importance of early stage venture investment to technology transfer and the exploitation of innovation, this difference in performance between Europe and the US should be of concern to policy makers. The role of early stage investment, notably in new technology, as a contributor to competitiveness and growth is acknowledged. In this respect, anecdotal evidence from market participants as well as an increasing body of research point to structural differences in the European and US markets as a contributing factor. There are significant differences in the conditions for the development stages preceding venture financing, notably in the financing of applied research and the role of business angels.

\subsection{Returns of US venture funds by vintage group}

Similarly to Chart 9 for Europe, Chart 13 presents the average cumulative IRRs since inception as of 31.12.2003 and 30.9.2006 for US venture funds established in 1983-2006.

Chart 13 


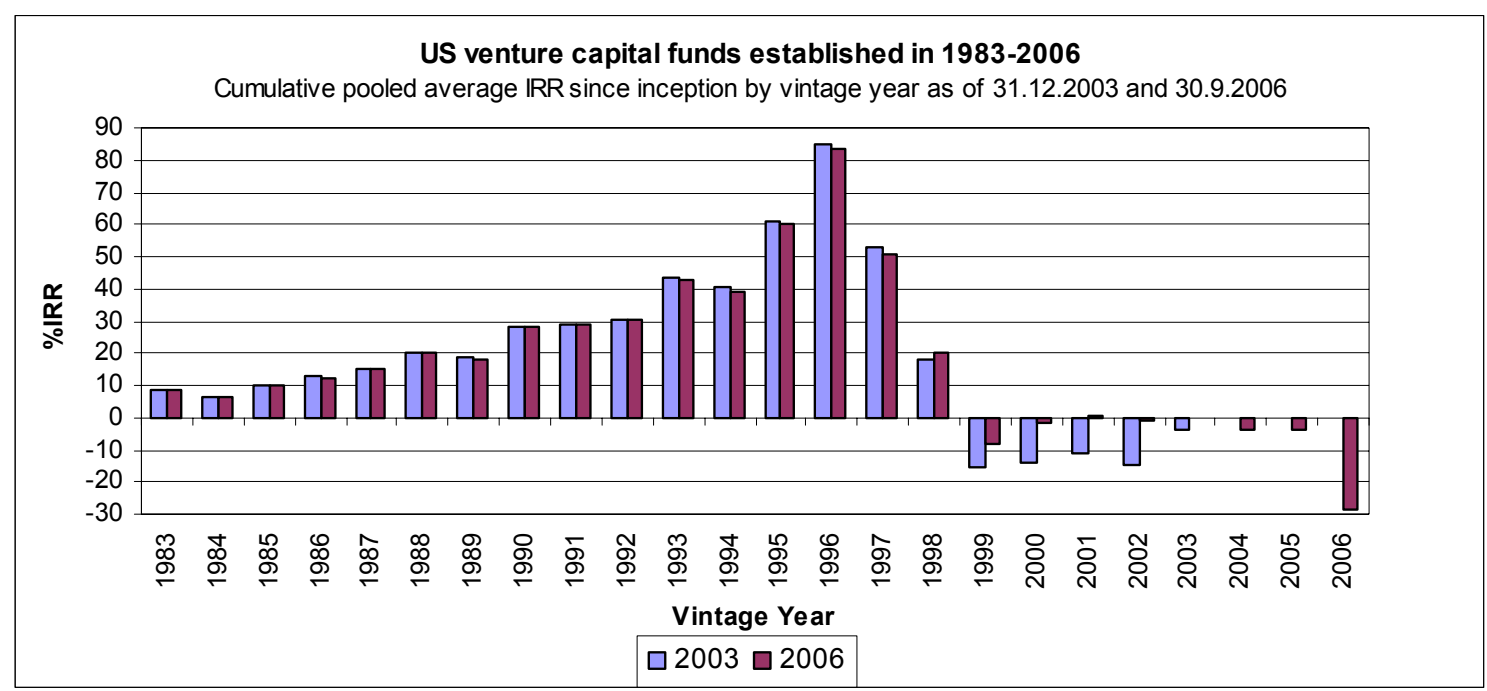

Data source: Thomson Financial

The main observation from the chart above is that the changes in the IRRs of US venture funds observed between the two reference points of end 2003 and end September 2006 are similar to Europe up to the 2000 vintage. In light of current data, certain vintages, notably 2001 and 2002, appear to be behind Europe in generating profits. However, given the immaturity of the funds concerned, it is impossible to predict whether or not the pecking order will be the same in five years time. It would seem clear that the early performance of more recent European funds is better than those belonging to pre-2000 vintages, but there is still every possibility that their US counterparts turn out to be equally or more profitable as the funds come closer to their divestment period.

A comparison of the profitability as of end September 2006 of European and US venture capital funds grouped by vintage year in Chart 14 below further illustrates the relative improvement in the performance of European venture investing. (It should be noted the European 2006 vintage is empty, no new funds having been included in the database for the year.)

\section{Chart 14}

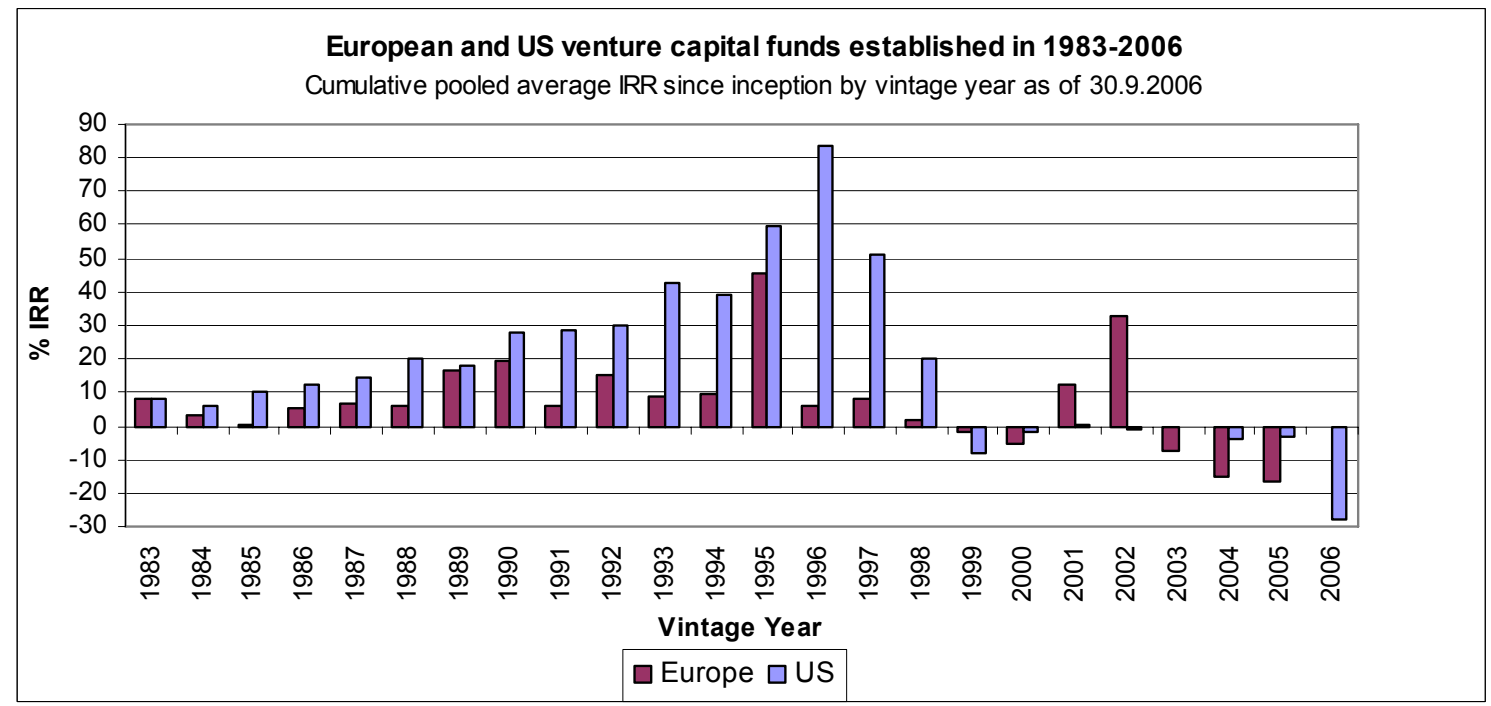

Data source: Thomson Financial 
A comparison of the cash distributions of European and US funds by vintage presented in Chart 15 below, further illustrates the apparent convergence of the two markets as far as the performance of post-2000 funds is concerned.

\section{Chart 15}

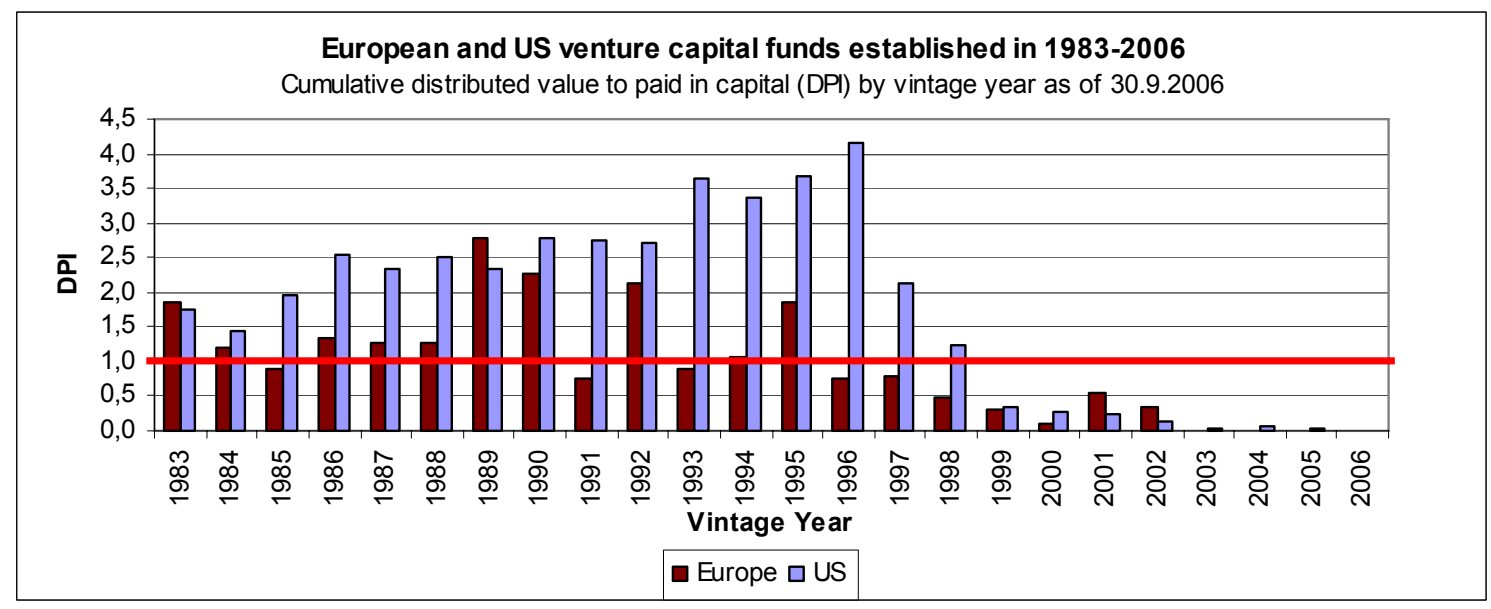

Data source: Thomson Financial

Previous research by Commission services using data as of end-2003 highlighted the unfavourable profitability differential of European venture capital investment in comparison with the United States ${ }^{15}$. Almost three years later in September 2006, the differential, despite having narrowed, still remained high, but applied mostly to liquidated funds. A number of active European funds belonging to more recent vintages appear to be outperforming US funds established in the same period. These groups of funds, though statistically representative they may be, do not have enough weight to influence the overall average profitability figures of the database, hence the persistence of the long investment horizon profitability gap between Europe and the US. From a European perspective there are grounds for optimism. However, confirmation of what seems to be a positive trend in European venture capital investment will only arrive in two or three years time, once the performance of funds in the recent vintages can be conclusively determined.

\section{A CLOSER LOOK AT EARLY-STAGE VENTURE INVESTMENT}

This final section seeks to identify factors that could help explain the fundamental differences in the European and US venture capital investment that have been illustrated in the previous sections. Early stage venture capital investment is an important element in the technology transfer value chain. Chart 16 below illustrates the profitability levels of the different venture segments as recorded at the end of 2003, 2004, 2005 and 2006. While the average returns produced by later stage venture investing are encouraging, early stage investing, which produced an overall 10 -year IRR of $-0.9 \%$ to the end of 2006, does not even break even. The profits made from successful early stage investments do not cover the losses made from others. The figures explain why early stage investment levels have remained low in Europe. This is in stark contrast with the 
United States, where the overall average profitability of early stage venture investment is respectable.

\section{Chart 16}

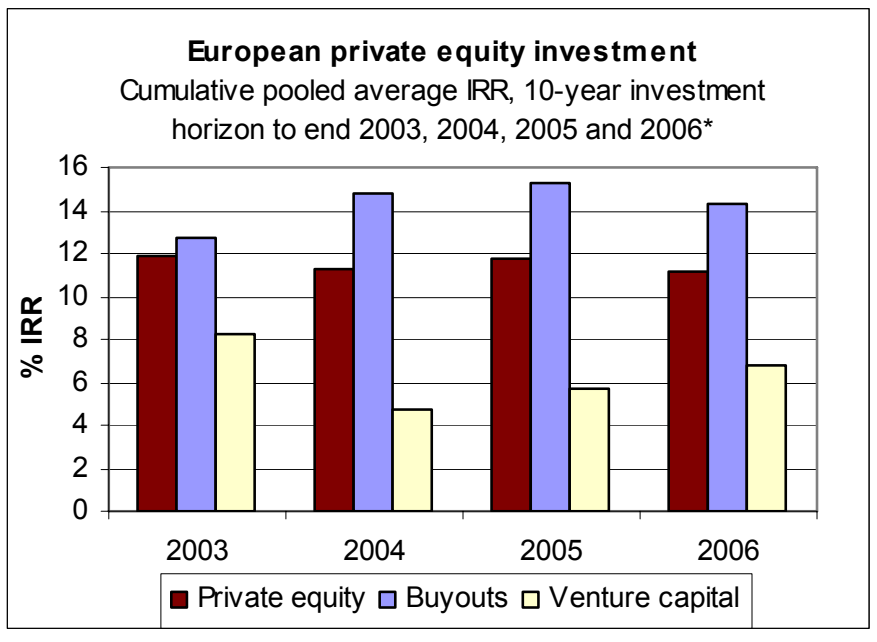

Data source: Thomson Financial; *2006 data as of 30.9.2006

Improving the attractiveness and thereby the role of early stage venture investing in Europe is one of the key challenges in creating strong innovation systems in Europe.

Are there such structural differences in the technology transfer chains between Europe and US that could make the environment for early stage venture investment more challenging in Europe and thereby reduce its productivity in the financing of innovation? Based on statistical information on numbers of investments and the average size of transactions, the early-stage venture investment practices appear distinctly different in Europe and the US, and could provide some clues to the performance differences.

Table 3

\begin{tabular}{|c|c|c|c|c|}
\hline \multicolumn{5}{|c|}{ Average annual no of companies receiving venture capital investments in 2003-2006 } \\
\hline $\begin{array}{l}\text { Investment phase } \\
\text { (EVCA definitions) }\end{array}$ & $\begin{array}{c}\text { Europe } \\
\text { No of companies }\end{array}$ & $\begin{array}{l}\text { Investment } \\
\text { phase } \\
\text { (NVCA } \\
\text { definitions) } \\
\end{array}$ & $\begin{array}{c}\text { US } \\
\text { No of companies }\end{array}$ & Europe/US \\
\hline Seed & 349 & Seed/start-up & 233 & $1.50 \mathrm{x}$ \\
\hline Start-up & 2142 & Early stage & 839 & $2.55 x$ \\
\hline Early stage & 2490 & Early stage & 1072 & $2.32 x$ \\
\hline Expansion & 3372 & Expansion & 1253 & $2.69 x$ \\
\hline $\begin{array}{l}\text { Replacement } \\
\text { capital }\end{array}$ & 314 & Later stage & 841 & $0.37 x$ \\
\hline Later stage & 3686 & Later stage & 2094 & $1.71 x$ \\
\hline Total & 6179 & Total & 3166 & $1.95 x$ \\
\hline
\end{tabular}

Data source: EVCA, The MoneyTree ${ }^{\mathrm{TM}}$ Survey, own calculations

Firstly, the number of companies that receive venture investments is very much higher in Europe than in the US despite the very much longer traditions venture investing in the US. As shown by Table 3, this phenomenon is particularly marked in the case of early stage companies. During the period 2003-2006, the average number of early stage companies financed by European venture funds was 2.3 times the US figure. Given the 
low profitability of European venture investment this seems to contradict economic logic.

Table 4

\begin{tabular}{|c|c|c|c|c|}
\hline \multicolumn{5}{|c|}{ Average deal size of venture capital investment in 2003-2006 } \\
\hline $\begin{array}{l}\text { Investment stage } \\
\text { (EVCA definitions) }\end{array}$ & $\begin{array}{c}\text { Europe } \\
(€ \text { millions) }\end{array}$ & $\begin{array}{l}\text { Investment stage } \\
\text { (NVCA definitions) }\end{array}$ & $\begin{array}{c}\text { US } \\
\text { (€ millions) }\end{array}$ & Europe/US \\
\hline Seed & 0.425 & Seed/start-up & 2.181 & $0.19 x$ \\
\hline Start-up & 1.425 & Early stage & 3.449 & $0.41 x$ \\
\hline Expansion & 2.652 & Expansion & 6.011 & $0.44 \mathrm{x}$ \\
\hline $\begin{array}{l}\text { Replacement } \\
\text { capital }\end{array}$ & 7.208 & Later stage & 7.699 & $0.94 x$ \\
\hline
\end{tabular}

$€ / \$: 1.317$

An equally surprising picture emerges from the comparison of average venture capital deal sizes in Europe and the US, as shown by the figures in Table 4. There is a substantial difference in average investment sizes. This difference is particularly marked in very early stage investment where the average European investment is just $€ 0.4$ million against $€ 2.2$ million in the US. The apparent scale difference in the European and US venture capital deal sizes is obviously strongly influenced by the exchange rate used. Should the two currencies be closer to parity, the difference would be wider.

The simultaneous high number of early stage investments, small investment amounts and the high probability of failure of those investments in Europe would be consistent with innovative projects being financed before they have been developed to a level where they are able to withstand the immediate commercial pressures that are inherent with venture capital financing. Venture capital could be used prematurely for lack of alternatives. Technologically promising projects may not be 'investment ready'. The capacity of US universities to foster commercially oriented research could be an element in helping to ensure that commercialisation is preceded by a sufficient preparatory phase, which also serves to eliminate non-starters. In this respect, the US tradition of philanthropic financing of research plays a role, as does the encouragement provided by the Bayh-Dole Act.

The above interpretation of the comparative European and US venture capital statistics would appear to be consistent with the relevant findings of the Lambert Review ${ }^{16}$, which, inter alia, assesses the various links of the technology-transfer chain in the UK in depth.

The role of business angels in preparing young companies for venture financing in the US should also not be overlooked. According to the Center for Venture Research of University of New Hampshire, US business angels invested \$25.6 billion in 51.000 projects in 2006. For Europe there exists little statistical information on business angel investment. The European Business Angel Network (EBAN), an association of European networks, recorded a total of $€ 149$ million invested in 843 projects in 2006 . It has to be

16 The Lambert Review on Business-University Collaboration, 2003, www.lambertreview.org.uk 
assumed that EBAN's figures only capture a small part of the market. Nevertheless, it seems fair to conclude that the role of angel investment is low in Europe, which lacks the 'conveyer belt' that should screen and prepare projects for venture investment.

The US Department of Defence SBIR programme for externalised research projects and the US federal procurement goals for small businesses should also be mentioned as market driven mechanisms that assist small companies, whether venture-backed or not, to generate revenues by assuring them access to public procurement programmes.

\section{PRIVATE EQUITY WORLD MARKETS}

Despite the scarcity of publicly available market data, it appears clear that the future size and shape of private equity markets will increasingly be influenced by investment activity in emerging markets by local and cross-border investors.

Perhaps the most compelling example is the Chinese market, where according estimates by PricewaterhouseCoopers annual private equity investment is of the order of $\$ 13$ billion, a figure comparable to that of France. Regarding venture capital investment in China, in 2006 it amounted to \$1.8-1.9 billion according to estimates by Zero2IPO China Venture Capital Report and Ernst\&Young/DowJones/VentureOne. The Chinese private equity market expansion seems to rely on the influx of capital from US buyout and venture capital funds, although part of the capital invested is raised locally. Venture capital investment in China is concentrated in the IT sector and geographically, in the Beijing and Shenzhen regions.

Private equity investment in Japan amounted to $\$ 7.95$ billion in 2005 according to PricewaterhouseCoopers. Other Asian countries with emerging private equity markets include Singapore, Korea, India, New Zealand, Indonesia, Malaysia and Taiwan. In Latin America, Brazil is the most important regional player by far with approximately $\$ 1$ billion of private equity investment in 2006 according to the Brazilian Venture Capital Association (ABVCAP).

\section{CONCLUDING REMARKS}

The macro-economic conditions that prevailed the period 2005-2006 were benign for the European buyout and venture capital industry leading to record breaking figures in fundraising, investments and exits. The industry records achieved in 2006 also suggest that the industry has matured and became more competitive. The period, which is the latest for which data is available, was characterised by optimism in both venture capital and private equity investment communities. The substantial worsening of conditions in the global financial markets starting August 2007 can be expected to have a negative impact on the buyout funds that leveraged their deals particularly highly. The impact would be felt via a rising burden of the debt charges carried by portfolio companies that have absorbed the private equity acquisition debt, the consequent lower earnings leading to lower asset valuations for investors. The particularly high fund raising level recorded in 2006 will also have come under pressure in 2007 as it becomes increasingly clear that market conditions do not encourage private equity investment the same way as the year before. 
Long investment horizon performance indicators make it clear that European buyout investment is attractive and largely outperforms US equivalent investment. As far as venture capital investment is concerned the picture is mixed. In historic terms, the unfavourable profitability gap between European and US venture capital investment remains almost unchanged, meaning in particular persistently low average returns generated by European early stage venture investment. Despite the historic averages, however, there seems to be a breed of young venture capital European funds, notably in the 2001 and 2002 vintages that are so far delivering better returns and outperforming the equivalent US funds.

Investment in venture capital progressed favourably in Europe as a result of the reducing impact the dotcom bubble on fund performance and the improved attitude of investors towards the asset class. The returns of venture capital investment over the long run, and consequently the levels of investment, may rise if the market offers more realistic investment opportunities. The quality of early stage investment deal flow is affected by structural factors which appear to be linked to how well the research and business communities are connected and the effectiveness of technology transfer structures. Improving the functioning of the pre-venture stages of the exploitation of technological innovation should be closely connected to policies aimed at the strengthening of the European venture capital market. The role of early-stage technology development investors, including business angels, specialized government bodies, foundations, family offices and early stage venture capitalists, need to be better understood and quantified with a view to better connecting them with the formal venture capital market.

\section{0}




\section{ANNEX I}

\section{PRIVATE EQUITY PERFORMANCE INDICATORS ${ }^{17}$}

An IRR calculation of a venture capital fund takes account of both cash and non-cash movements in assets. Negative cash flows would include payments for investments and management fees. Positive flows would include all cash payments made by the fund to its investors whether resulting from exits from investments or dividends received from the investee companies, and the net asset value of the investments held by the fund. From a mathematic point of view the return rate calculated (IRR) is the one resulting from equalling to zero all cash-flows associated to the investment made.

The IRR of a fund may be calculated for different periods depending on the specific purpose of the return calculation or the benchmarks used by the investor itself. Typically, the following IRR calculations are applied:

- Cumulative IRR since inception calculates the return of a fund since its commencement of operations. Cumulative return since inception captures the total return that a fund has produced during its life up the reference point. It lends itself for the comparison of the performance of individual funds established in the same year with the assumption that all are similarly affected by the J-curve effect. It also permits the comparison of different fund vintages.

- Investment horizon IRR calculates the return generated by a fund during a past fixed period, typically over $1,3,5,10$ or 20 years up to the most recent date for which data is available, for instance 31.12.2003. Investment horizon returns permit the examination of venture capital returns against the backdrop of the prevailing economic conditions.

For an indication of the performance of a group of funds, the commonly used measure is the 'pooled average', which treats the relevant sample as one fund. Unless otherwise defined, the averages in this paper are pooled averages.

The 'vintage year IRR' is particularly useful for comparing the performance of a single fund with a group of similar funds. Comparing average pooled returns of different vintage years also provides an illustration of how groups of funds evolve and are affected by the economic conditions prevailing during the funds' life span.

Investment multiples measure the profitability of a venture capital fund by calculating the return of the funds as a multiple of the original investment as follows:

TVPI $=$ DPI + RVPI

- TVPI is the Total Value of the fund's investments over Paid In capital

- DPI is Distributions over Paid In capital and corresponds to the realised portion of the fund return calculated on the basis of cash-out/cash-in

17 The content of this section was extracted from the paper "Profitability of the venture capital investment in Europe and the United States", note to the EFC dated 29 September 2004, later published in DG ECFIN Economic Papers series as Number 245". 
- RVPI is the Residual Value of the fund assets over Paid In capital and corresponds to the unrealised portion of the return

Investment multiples are performance indicators that establish a distinction between the realised and unrealised portions of the total return of a venture capital fund or an investment in a venture capital fund. They do not take account of the time value of money. 


\section{ANNEX II}

\section{DATA SOURCES}

The private equity investment performance data has kindly been made available by Thomson Financial. Thomson Financial, building on the legacy of Thomson Venture Economics, has developed over the last 35 years a database of fund performance data for the private equity and venture capital in Europe and the US, called VentureXpert ${ }^{\mathrm{TM}}$. It covers both European and US data. Currently the VentureXpert ${ }^{\mathrm{TM}}$ database covers 1091 funds European funds formed between 1980 and 2005 up from 887 in 2003 (funds formed between 1980 and 2003). The US dataset it contains 1923 private equity funds formed between 1969 and 2006 up from 1705 in 2003.

The performance data used in this note was extracted from the database in April 2007. The data in the database is continuously updated and therefore subject to change. The figures used correspond to fund performance as at 30.9.2006. The figures should not be significantly different from the 2006 year end figures.

Data on China private equity was kindly provided free of charge by Zero2IPO - China Venture Capital Report, a commercial data provider, following recommendation of the China Venture Capital Association.

\section{Miscellaneous}

The exchange rates used to convert US dollars into euros were the average annual exchange rates taken from AMECO database, i.e. EUR/USD 1.0658 in 1999, 0.9236 in 2000, 0.8956 in 2001, 0.9456 in 2002, 1.1312 in 2003, 1.2439 in 2004, 1.2441 in 2005 and 1.2556 in 2006. GDP figures (market prices) were also taken from AMECO. 